\title{
Machine Learning Aids Classification and Discrimination of Non-canonical DNA Folding Motifs by an Arrayed Host:guest Sensing System
}

\author{
Junyi Chen, ${ }^{2}$ Adam D. Gill, ${ }^{3}$ Briana L. Hickey, ${ }^{1}$ Ziting Gao, ${ }^{1}$ Xinping Cui, ${ }^{4}$ \\ Richard J. Hooley ${ }^{1,3 *}$ and Wenwan Zhong ${ }^{1,2 *}$ \\ ${ }^{1}$ Department of Chemistry; ${ }^{2}$ Environmental Toxicology Graduate Program; \\ ${ }^{3}$ Department of Biochemistry; ${ }^{4}$ Department of Statistics; University of California- \\ Riverside, Riverside, CA 92521, U.S.A. \\ E-mail: richard.hooley@ucr.edu; wenwan.zhong@ucr.edu
}

\section{Supporting Information}

\section{Table of Contents}

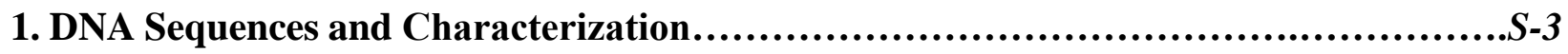

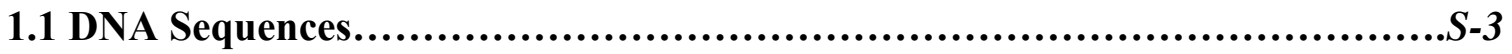

1.2 Circular Dichroism (CD) Spectra for DNA Folding Confirmation................S-4

1.3 Gel Electrophoresis for DNA Quality Inspection.................................S-8

2. NMR Spectra of Components Used........................................................

3. Fluorescence Spectra and Titration Curves..............................................

3.1 Fluorescence Spectra of Fluorescent Guests with Hosts/DNA....................S-11

3.2 Fluorescence Titration of Dye-DNA.............................................S-12

3.3 Fluorescence Titration of Host Addition to Dye•DNA Complexes ................S-13

4. Array Analysis for Differentiation of 7 DNAs.......................................

4.1 Bar Plots for Array Signals from 7 DNAs ...........................................S-17

4.2 PCA Plots with Different Host:Guest Array Elements Combinations ...........S-18

5. Array Analysis for Sensing 18 DNAs..................................................... 19 
5.1 Bar Plots for Array Signals from 18 DNAs $\ldots \ldots \ldots \ldots \ldots \ldots \ldots \ldots \ldots \ldots \ldots \ldots \ldots \ldots . . . . . . .19$

5.2 SVM plot of 18 DNA training set with 16-element Host:Guest Array............S-20

5.3 Performance metrics of DNA Structures Classification.............................S-21

6. Fluorescence response plots of the unknown DNA structures.........................S-22

6.1 Fluorescence response plots of unknown DNA structures ....................S-22

6.2 SVM decision boundary plot for prediction results..........................S-24

7. UV-Vis Absorption Spectra........................................................ 25

7.1 UV-Vis Spectra of Dye-DNA..............................................S-25

7.2 UV-Vis Spectra of DNA Addition to Dye•Host Complexes......................S-26

8. References........................................................................... 28 


\section{DNA Sequences and Characterization \\ 1.1 DNA Sequences}

Table $S$-1. DNA sequences used in this project.

\begin{tabular}{|c|c|c|c|c|c|}
\hline Group & Name & Sequence & Motif & Bases & Ref. \\
\hline \multirow{4}{*}{$\begin{array}{c}\text { DNA G4 } \\
\text { with/ } \\
\text { without } \\
\text { a } \\
\text { vacancy }\end{array}$} & $\begin{array}{c}\text { MYOG- } \\
3332 \\
\end{array}$ & AGGGTGGGCTGGGAGGT & $\begin{array}{c}\text { Parallel G4 with a } \\
\text { vacancy }\end{array}$ & 17 & \multirow{2}{*}{1} \\
\hline & $\begin{array}{c}\text { MYOG- } \\
3333 \\
\end{array}$ & AGGGTGGGCTGGGAGGGT & Parallel G4 & 18 & \\
\hline & HIF $1 \alpha-2333$ & AGGTGGGCGGGCTTGCGGGA & $\begin{array}{c}\text { Parallel G4 with a } \\
\text { vacancy }\end{array}$ & 20 & \multirow[t]{2}{*}{2} \\
\hline & HIF $1 \alpha-3333$ & AGGGTGGGCGGGCTTGCGGGA & Parallel G4 & 21 & \\
\hline \multirow{4}{*}{$\begin{array}{c}\text { DNA G4 } \\
\text { with/ } \\
\text { without } \\
\text { a bulge }\end{array}$} & hTR $1-20$ & GGGTTGCGGAGGGT GGG CCT & $\begin{array}{c}\mathrm{c} 1: \text { parallel }+ \\
\text { antiparallel G4 } \\
\text { c2: parallel } \\
\text { dimeric G4 }\end{array}$ & 20 & \multirow[t]{2}{*}{3} \\
\hline & $\begin{array}{c}\text { hTR } 1-20 \\
\text { original }\end{array}$ & GGGTTGGGAGGGTGGG CCT & Parallel G4 & 19 & \\
\hline & HT-T5 & $\begin{array}{c}\text { TTGGGTTAGGGTTAGTGGTTAGGG } \\
\text { A }\end{array}$ & $\begin{array}{l}\text { Hybrid G4 with a } \\
\text { bulge }\end{array}$ & 25 & \multirow[t]{2}{*}{4} \\
\hline & $\begin{array}{l}\text { HT-T5 } \\
\text { original }\end{array}$ & $\begin{array}{c}\text { TTGGGTTAGGGTTAGGGTTAGGG } \\
\text { A }\end{array}$ & Hybrid G4 & 24 & \\
\hline \multirow{3}{*}{ i-motif } & hTelo & CCCTAACCCTAACCCTAACCCT & i-motif (pH 4-7) & 22 & 5 \\
\hline & c-kit & CCCTCCTCCCAGCGCCCACCCT & i-motif (pH 5-6.8) & 22 & 6 \\
\hline & DIA & CССААТСССААТСССААТССС & $\begin{array}{l}\text { i-motif }(\mathrm{pH}=4.8) \\
\text { ssDNA }(\mathrm{pH}=7.6)\end{array}$ & 21 & 7 \\
\hline \multirow{4}{*}{ Triplex } & HD28 & $\begin{array}{c}\text { GAGAGAACCCCTTCTCTCTTTCTC } \\
\text { TCTT } \\
\end{array}$ & $\begin{array}{c}\text { Parallel triplex } \\
(\mathrm{pH} 5.5)\end{array}$ & 28 & 8 \\
\hline & HD31 & $\begin{array}{l}\text { AGAGAGAACCCCTTCTCTCTTTTT } \\
\text { CTCTCTT }\end{array}$ & $\begin{array}{l}\text { Parallel triplex } \\
(\mathrm{pH} \mathrm{5.5)}\end{array}$ & 31 & 9 \\
\hline & Triplex 6 & $\begin{array}{c}\text { TCCCTCCTTTTTGGAGGGATTTTT } \\
\text { TGGGTGG } \\
\end{array}$ & $\begin{array}{c}\text { Antiparallel } \\
\text { triplex (pH 5.6) }\end{array}$ & 31 & \multirow{2}{*}{10} \\
\hline & Triplex 7 & $\begin{array}{c}\text { TCCCTCCTTTTTGGAGGGATTTTT } \\
\text { AGGGAGG }\end{array}$ & $\begin{array}{c}\text { Antiparallel } \\
\text { triplex (pH 5.6) }\end{array}$ & 31 & \\
\hline \multirow[b]{2}{*}{ Hairpin } & 25 -mer & $\begin{array}{c}\text { CCCCTTAGTAGTTCCTCACAAGGG } \\
\text { G }\end{array}$ & hairpin & 25 & 11 \\
\hline & $1 \mathrm{NGO}$ & $\begin{array}{l}\text { CTCTTTTTGTAAGAAATACAAGGA } \\
\text { GAG } \\
\end{array}$ & hairpin & 27 & 12 \\
\hline \multirow{2}{*}{$\begin{array}{l}\text { Unibase } \\
\text { strand }\end{array}$} & $\mathrm{A} 20$ & AAAAAAAAAAAAAAAAAAAA & Unibase & 20 & $13-14$ \\
\hline & $\mathrm{C} 20$ & СССССССССССССССССССС & Unibase & 20 & 15 \\
\hline \multirow{5}{*}{ Predict } & $\begin{array}{c}\text { APE1-4 } \\
\text { track }\end{array}$ & TACCCACCCCCACCCTGCCCTG & i-motif (pH 5) & 22 & 16 \\
\hline & c-myc 2345 & TGAGGGTGGGGAGGGTGGGGAA & Parallel G4 & 22 & $17-19$ \\
\hline & G20 & GGGGGGGGGGGGGGGGGGGG & $\begin{array}{c}\text { Parallel G4 or w/ } \\
\text { bulges }\end{array}$ & 20 & 20-22 \\
\hline & EAD4 & CTGGGTTGGGTTGGGTTGGGA & Parallel G4 & 21 & 23 \\
\hline & Telo24 & $\begin{array}{l}\text { TTAGGGTTAGGGTTAGGGTTAGG } \\
\text { G }\end{array}$ & Hybrid G4 & 24 & 24 \\
\hline
\end{tabular}




\subsection{Spectra for DNA Folding Confirmation}
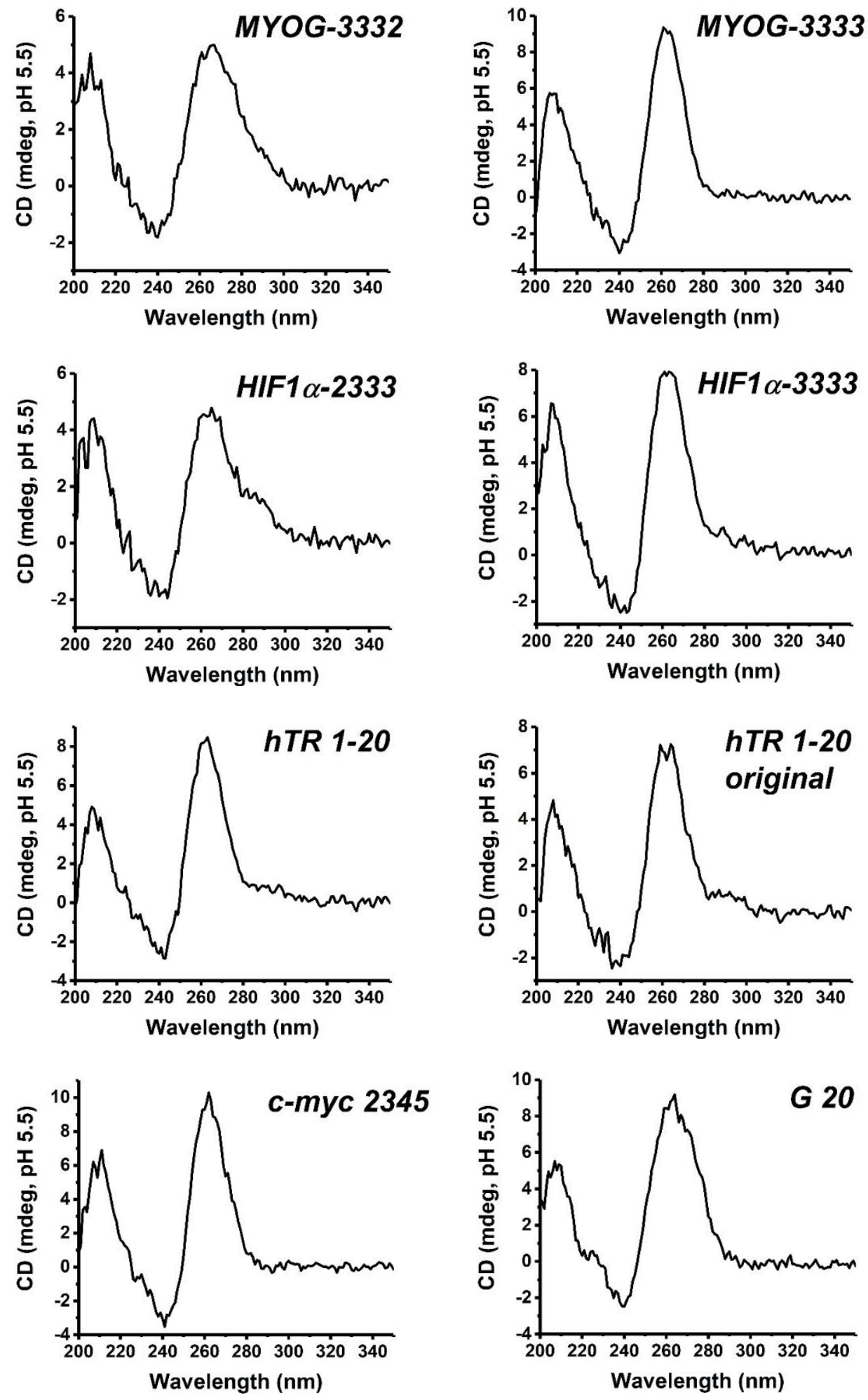

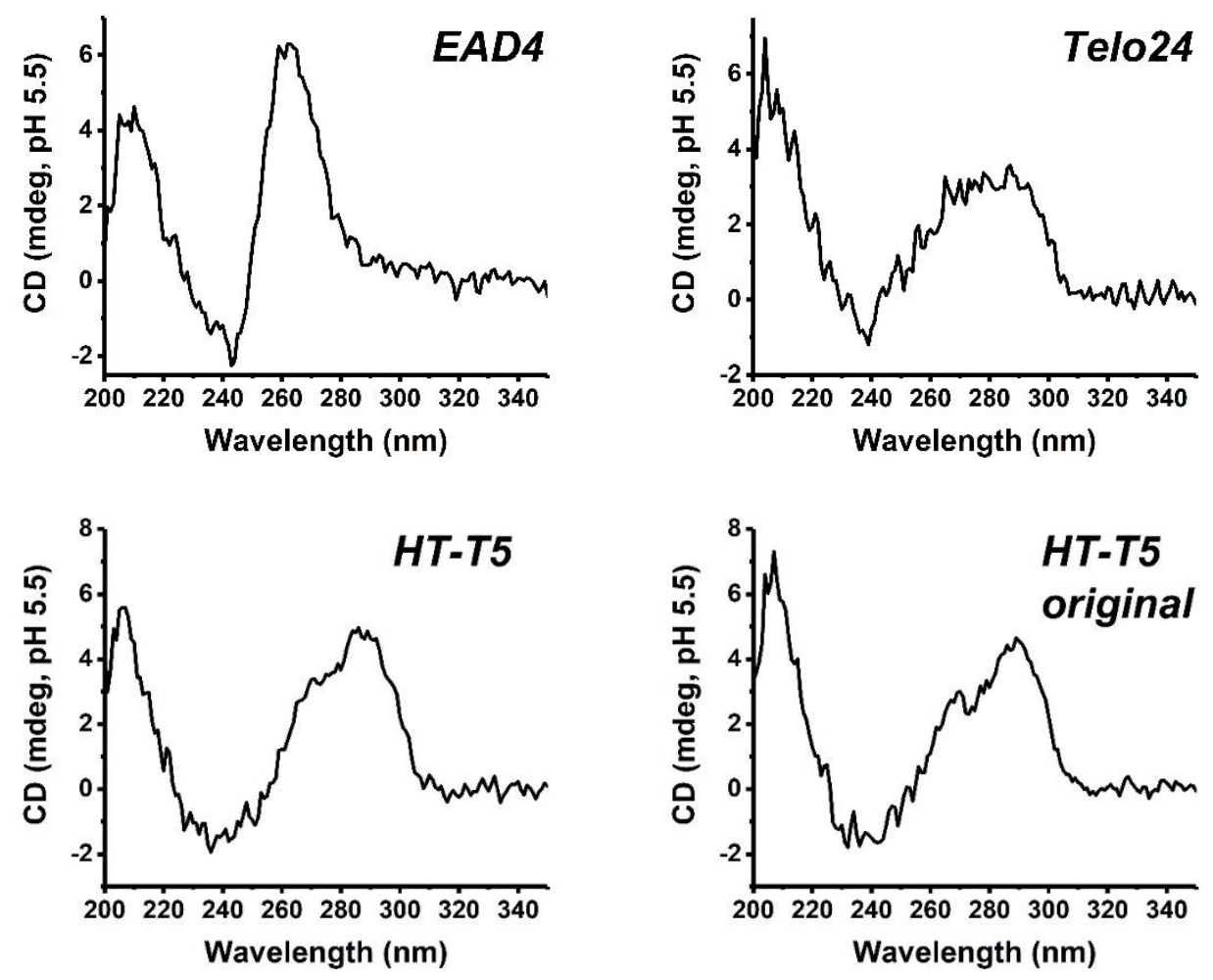

Figure $S$-1a. CD spectra with baseline correction of $10 \mu \mathrm{M}$ G4 DNA in $20 \mathrm{mM} \mathrm{CH}_{3} \mathrm{COOK} 5 \mathrm{mM} \mathrm{MgCl}_{2}$ $\mathrm{pH}$ 5.5. DNA was denatured at $95^{\circ} \mathrm{C}$ for $5 \mathrm{~min}$, cooled on ice for $10 \mathrm{~min}$ and then held at room temperature for $30 \mathrm{~min}$ before the experiment. 

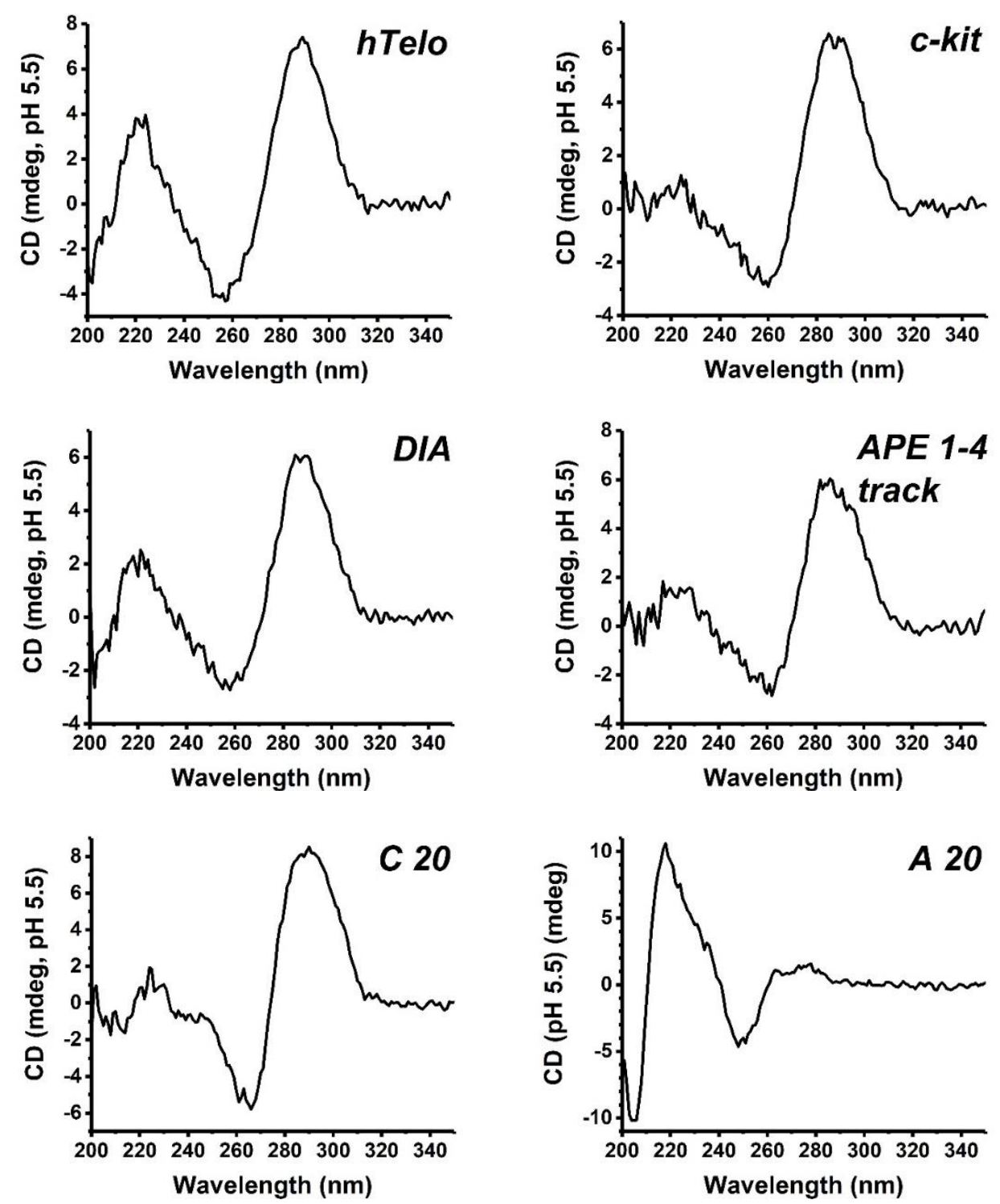

Figure $S$-1b. CD spectra with baseline correction of $10 \mu \mathrm{M}$ i-motif and C20/A20 DNA. Other conditions are identical to those described in Figure $S$-1a. 

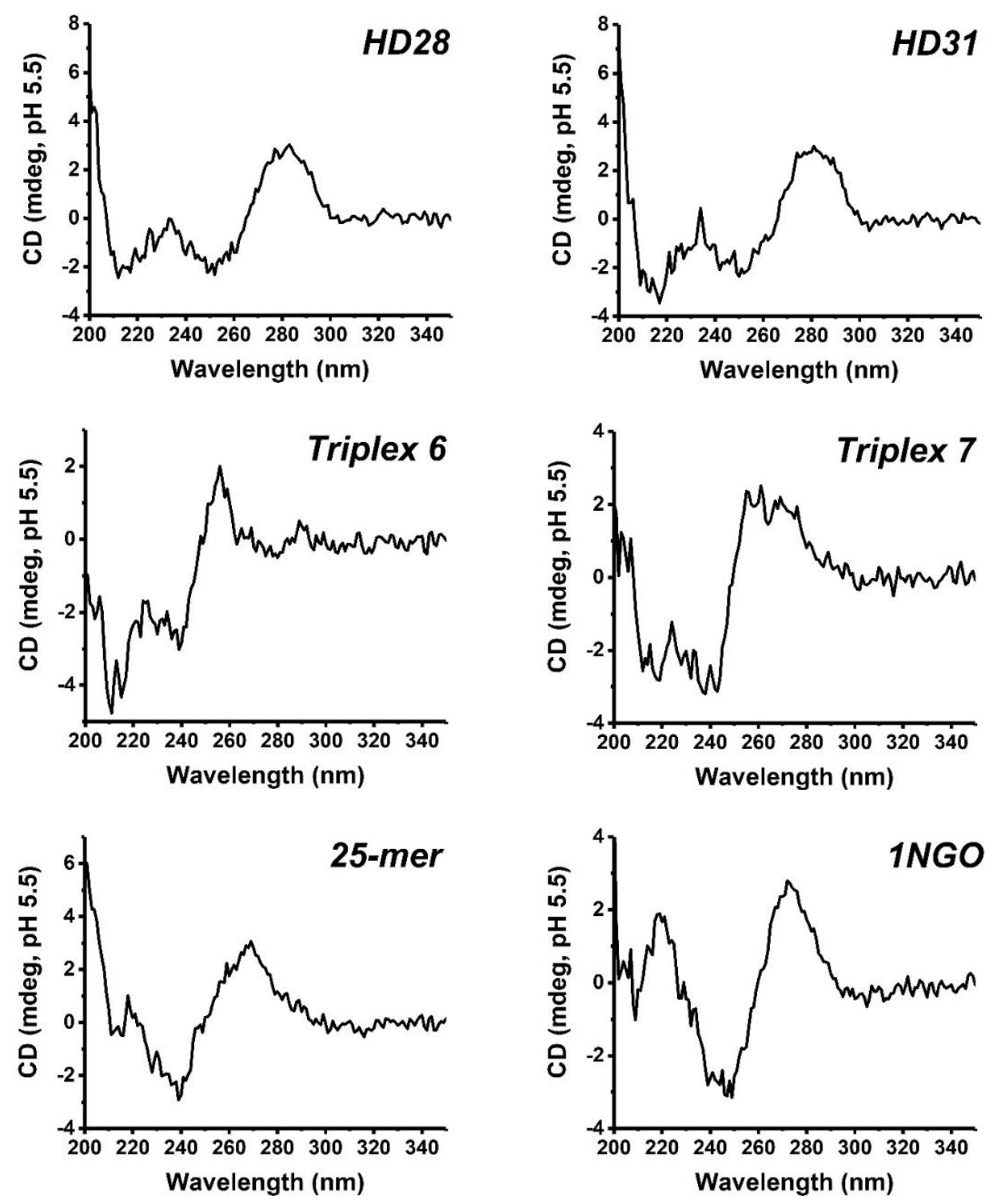

Figure $S$-1c. CD spectra with baseline correction of $10 \mu \mathrm{M}$ triplex and hairpin DNA. Other conditions are identical to those described in Figure $S$-1a. 


\subsection{Gel Electrophoresis for DNA Quality Inspection}

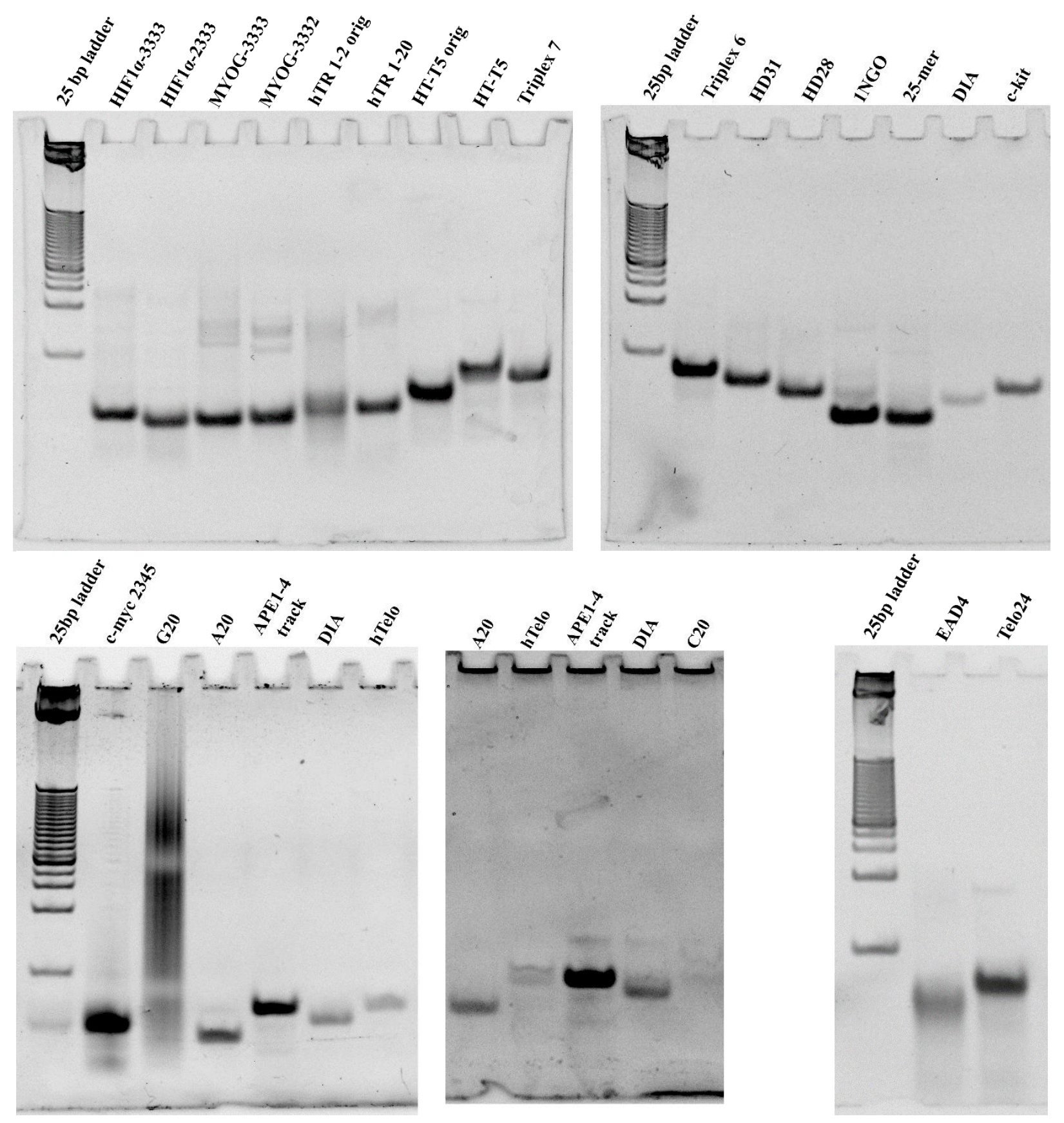

Figure $S$-2. The gradient native polyacrylamide gel electrophoresis (PAGE) gel (4\%-20\%) results of DNA sequences. The gel was loaded with $5 \mu \mathrm{l}(10 \mu \mathrm{l}$ for hTelo and C20) of a $2 \mu \mathrm{M}$ DNA dissolved in $20 \mathrm{mM}$ $\mathrm{CH}_{3} \mathrm{COOK} 5 \mathrm{mM} \mathrm{MgCl} 2 \mathrm{pH} 5.5$ buffer, which had been denatured at $95^{\circ} \mathrm{C}$ for $5 \mathrm{~min}$, cooled on ice for $10 \mathrm{~min}$ and then held at room temperature for $30 \mathrm{~min}$. The gel was run at $120 \mathrm{~V}$ for $60 \mathrm{~min}$ at room temperature in $1 \times$ TBE buffer and stained with SYBR Gold (1.5:10000 dilution) before imaging using a UV transilluminator (SPECTROLINE). 


\section{NMR Spectra of Components Used}

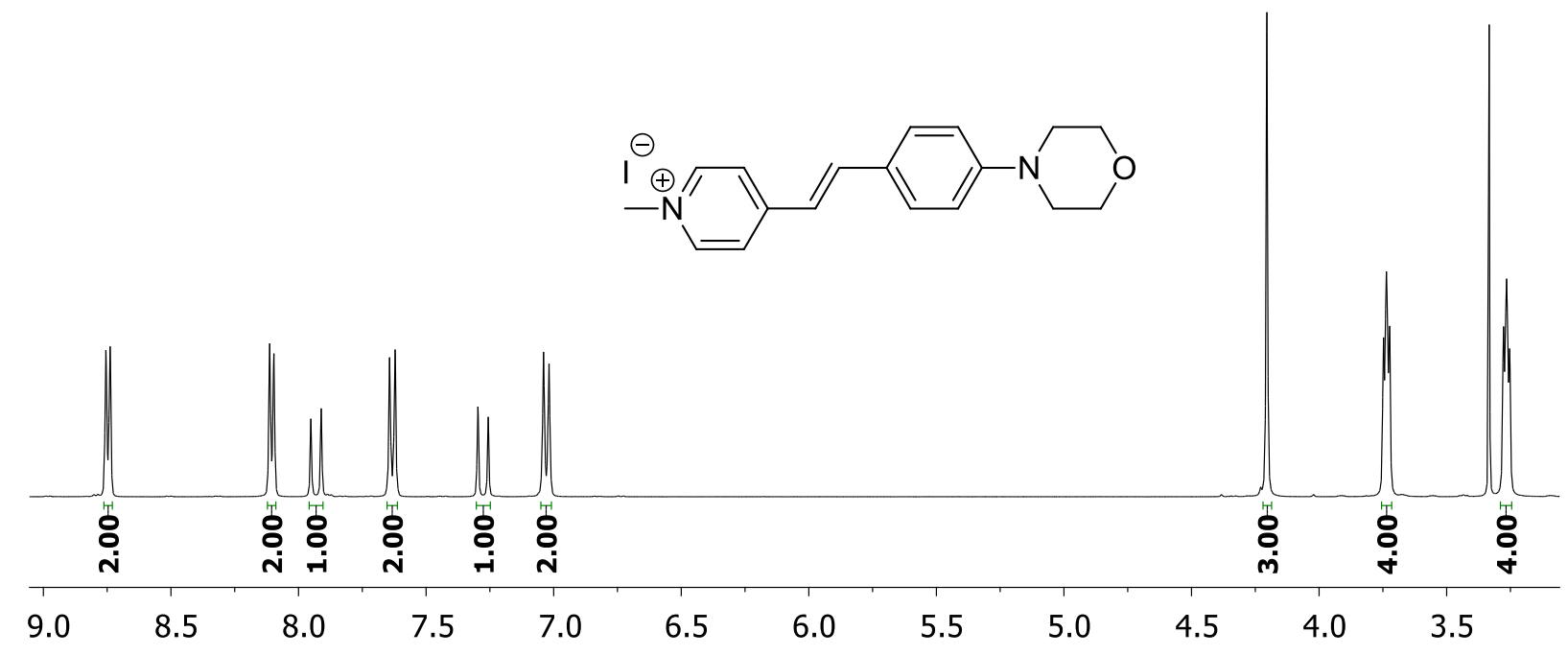

Figure $S$-3. ${ }^{1} \mathrm{H}$ NMR spectrum of MSMI (400 MHz, $298 \mathrm{~K}$, DMSO- $d_{6}$ ).

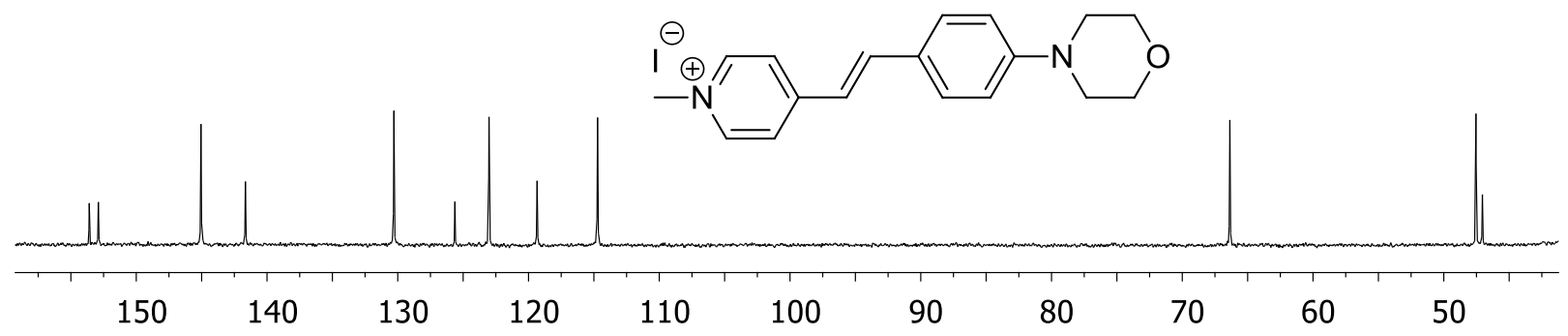

Figure $S-4 .{ }^{13} \mathrm{C}$ NMR of MSMI (100 MHz, $298 \mathrm{~K}$, DMSO- $d_{6}$ ).

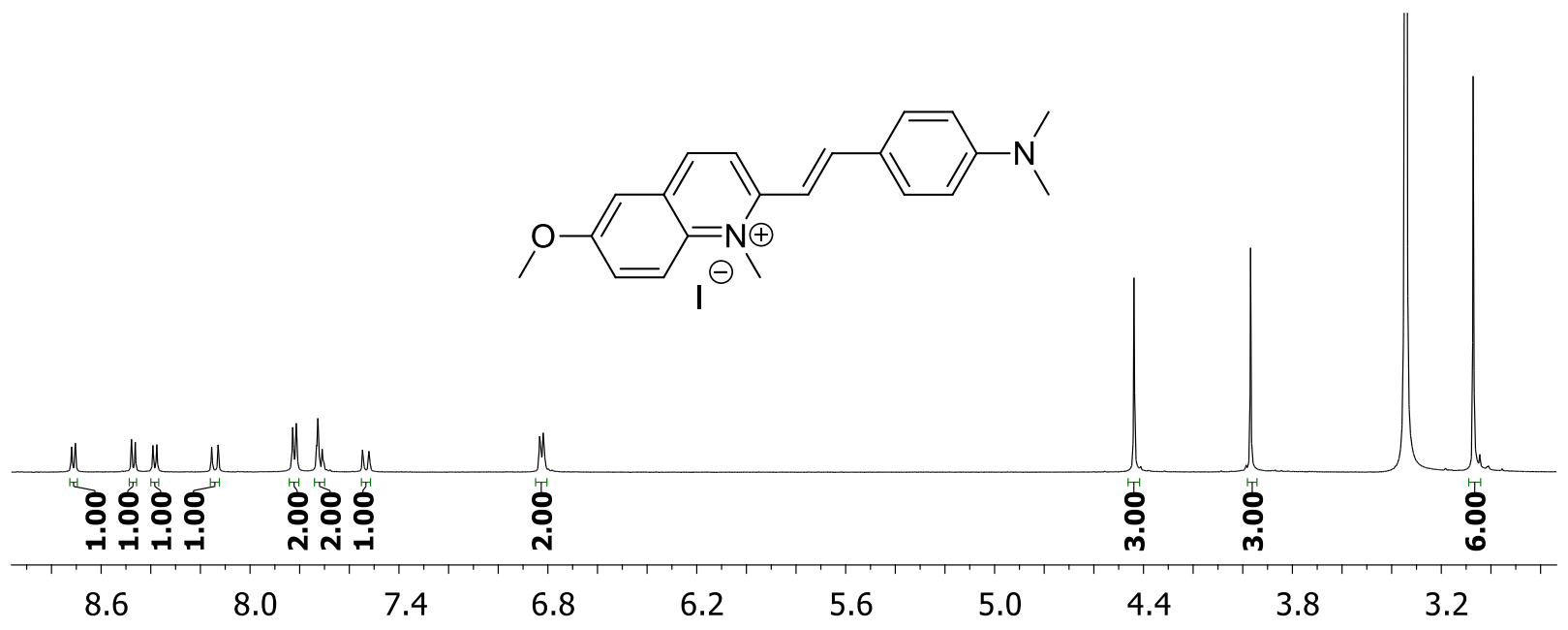

Figure $S$-5. ${ }^{1} \mathrm{H}$ NMR spectrum of DQMI (600 MHz, $298 \mathrm{~K}$, DMSO- $d_{6}$ ). 


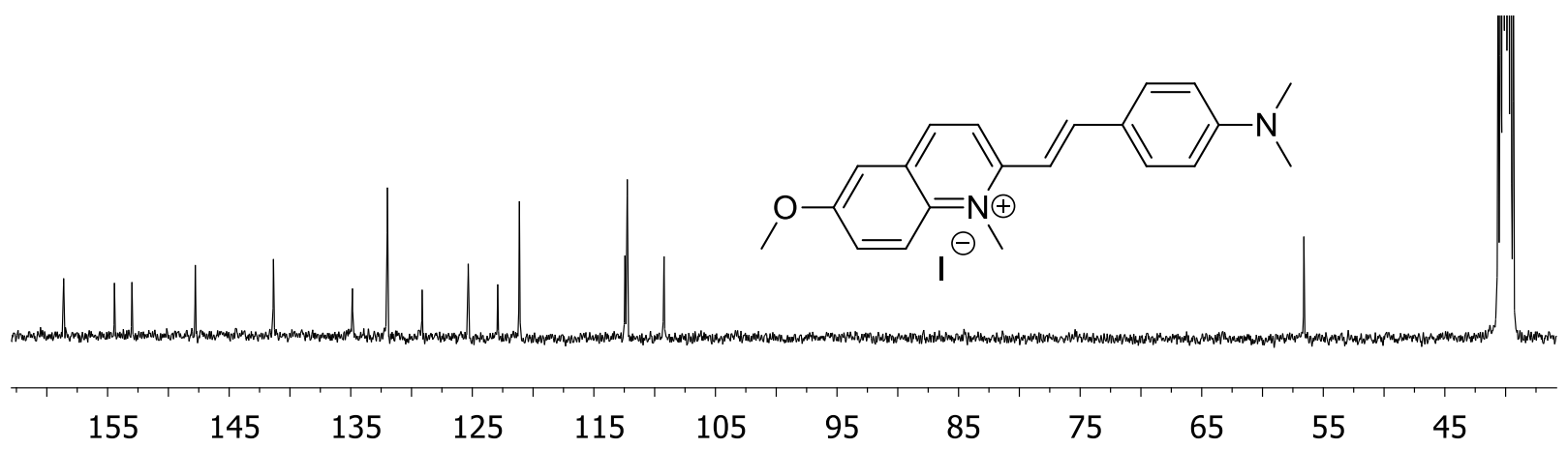

Figure $S$-6. ${ }^{13} \mathrm{C}$ NMR of DQMI (100 MHz, $298 \mathrm{~K}$, DMSO- $d_{6}$ ). 


\section{Fluorescence Spectra and Titration Curves}

\subsection{Fluorescence Spectra of Fluorescent Guests with Hosts/DNA}

a)
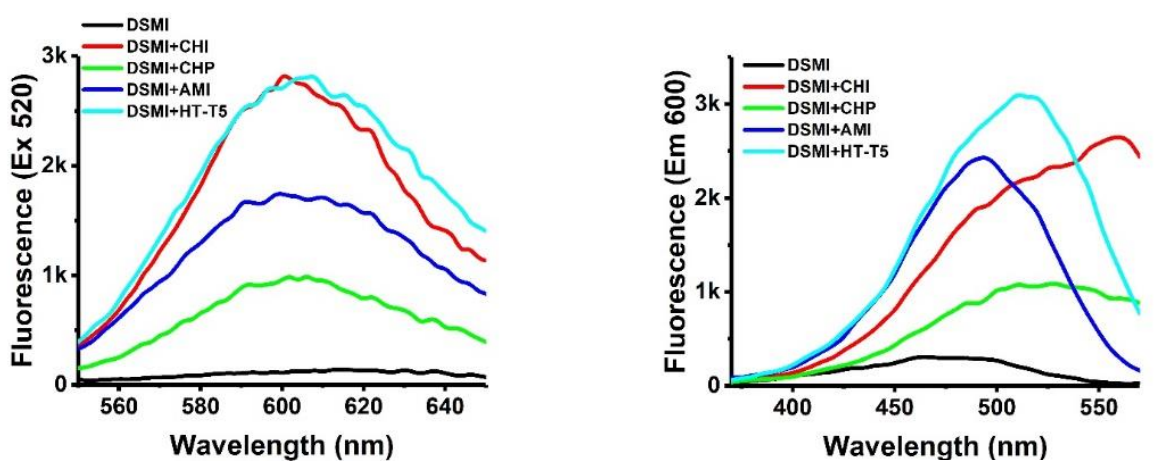

b)
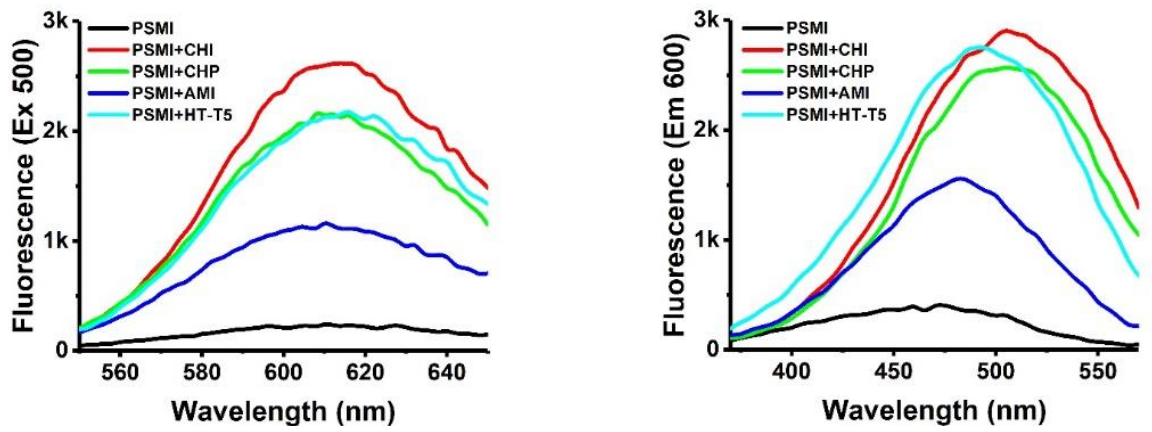

c)
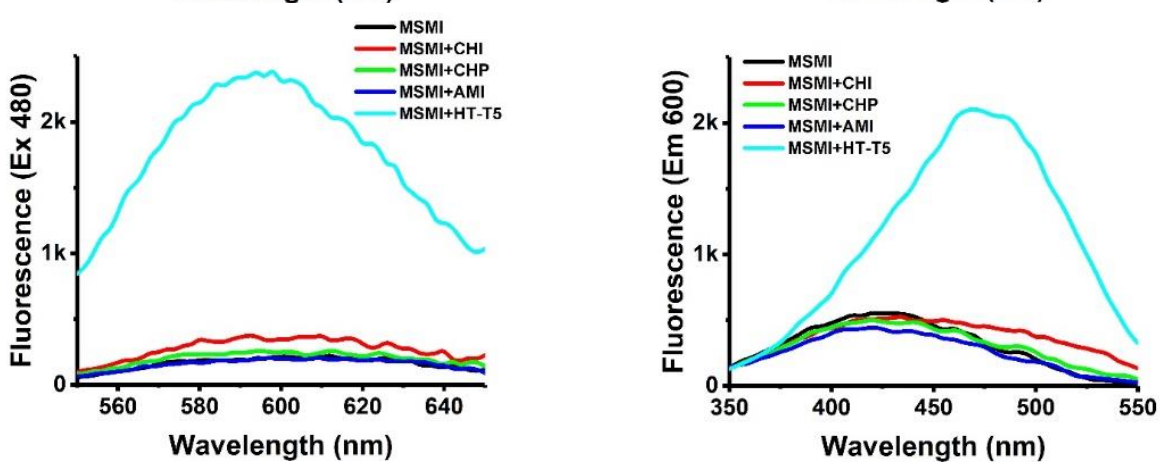

d)
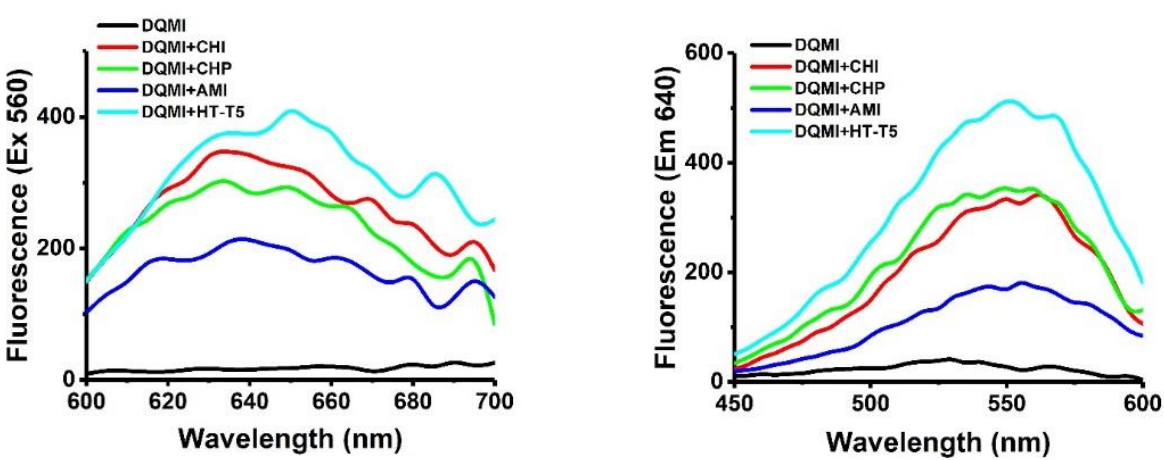

Figure S-7. Emission (left) and excitation (right) fluorescence spectra of Dye a) DSMI, b) PSMI, c) MSMI, and d) DQMI with CHI/CHP/AMI/HT-T5. Left: emission spectra; Right: excitation spectra. $[$ Dye $]=0.625 \mu \mathrm{M},[\mathbf{C H I} / \mathbf{C H P} / \mathbf{A M I}]=4 \mu \mathrm{M},[\mathrm{HT}-\mathrm{T} 5]=0.2 \mu \mathrm{M}, 20 \mathrm{mM} \mathrm{CH}_{3} \mathrm{COOK}, 5 \mathrm{mM} \mathrm{MgCl} 2, \mathrm{pH} 5.5$ buffer. 


\subsection{Fluorescence Titration of Dye-DNA}
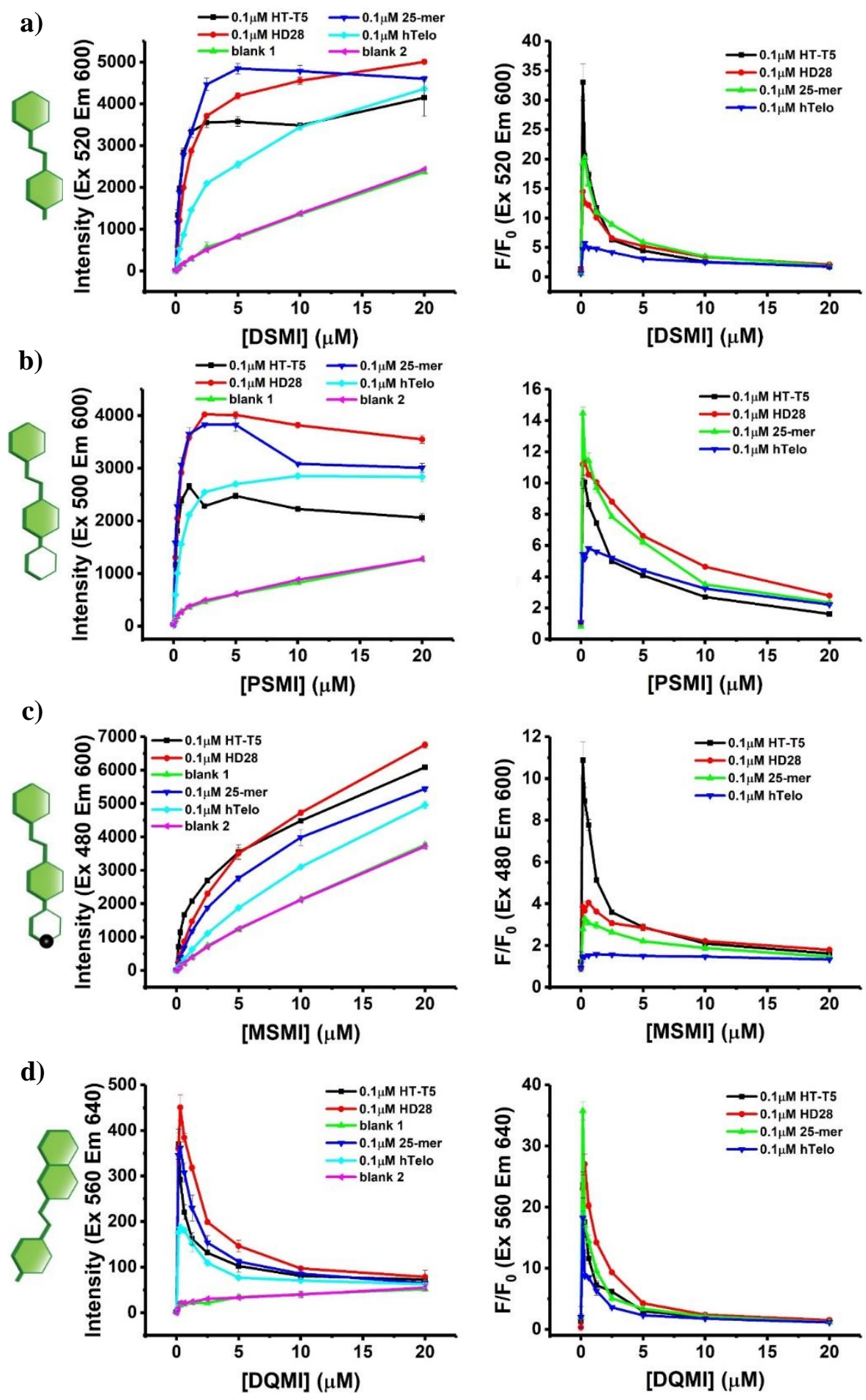

Figure $\boldsymbol{S - 8}$. Fluorescence response curves of HT-T5, HD28, 25-mer hairpin or hTelo with increasing concentration (0-20 $\mu \mathrm{M}$ ) of Dye a) DSMI, b) PSMI, c) MSMI, and d) DQMI. Left: plots using the raw fluorescence counts; Right: plots using the fluorescence normalized against that of the dye $\left(\mathrm{F}_{0}\right.$ being the dye fluorescence in the absence of DNA). [Dye] $=0-20 \mu \mathrm{M}$, [DNA] $=0.1 \mu \mathrm{M}, 20 \mathrm{mM} \mathrm{CH}_{3} \mathrm{COOK}, 5 \mathrm{mM}$ $\mathrm{MgCl}_{2}, \mathrm{pH} 5.5$ buffer. 


\subsection{Fluorescence Titration of Host Addition to Dye•DNA Complexes}

a)

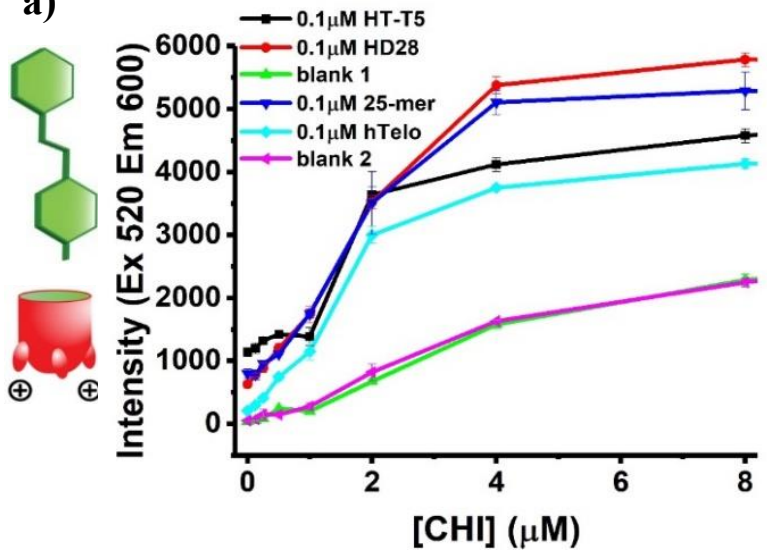

b)

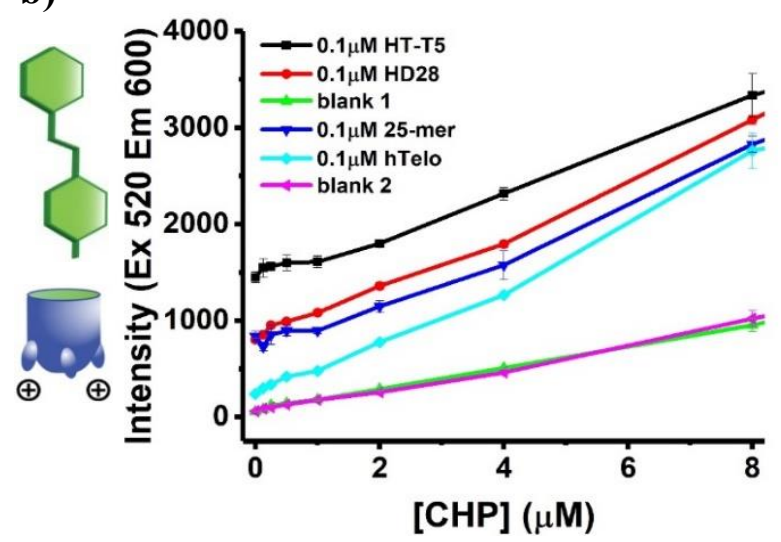

c)

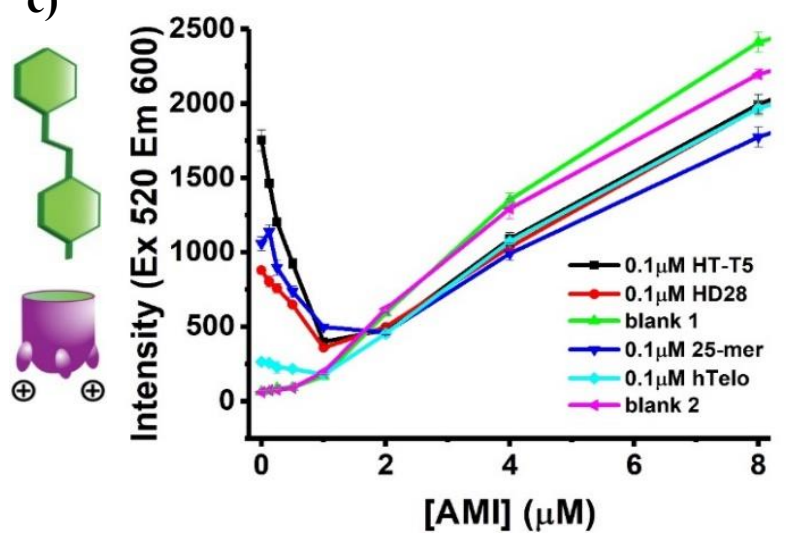

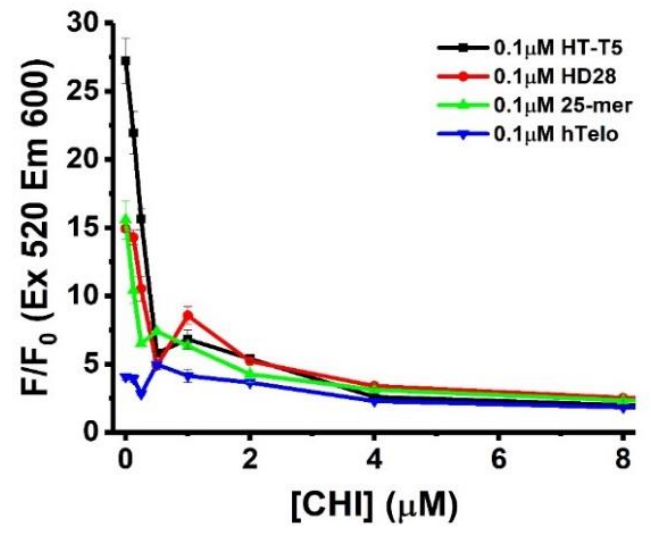
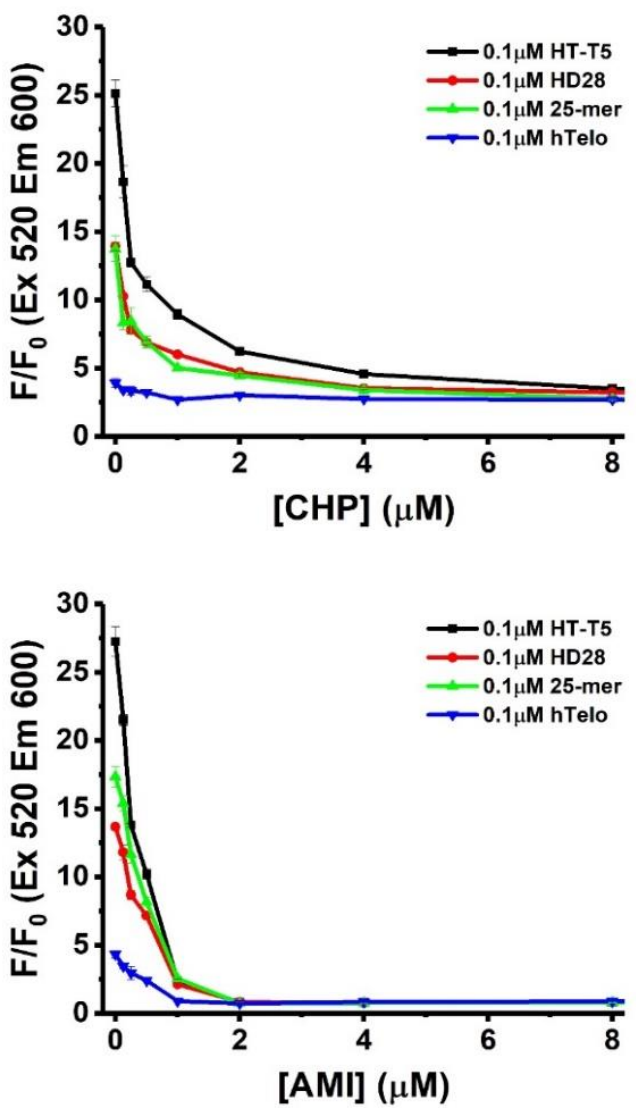

Figure $S$-9. Fluorescence response curves of DSMI-DNA complexes upon titration of hosts: a) CHI, b) CHP, and c) AMI. Left: the raw fluorescence counts (DSMI + Host); Right: plots normalized to the response of cavitand-DSMI in the absence of DNA $\left(\mathrm{F}_{0}\right)$. [DSMI $]=0.15625 \mu \mathrm{M},[\mathrm{DNA}]=0.1 \mu \mathrm{M}$, [Host] $=0-16 \mu \mathrm{M}, 20 \mathrm{mM} \mathrm{CH}_{3} \mathrm{COOK}, 5 \mathrm{mM} \mathrm{MgCl}_{2}, \mathrm{pH} 5.5$ buffer. 
a)
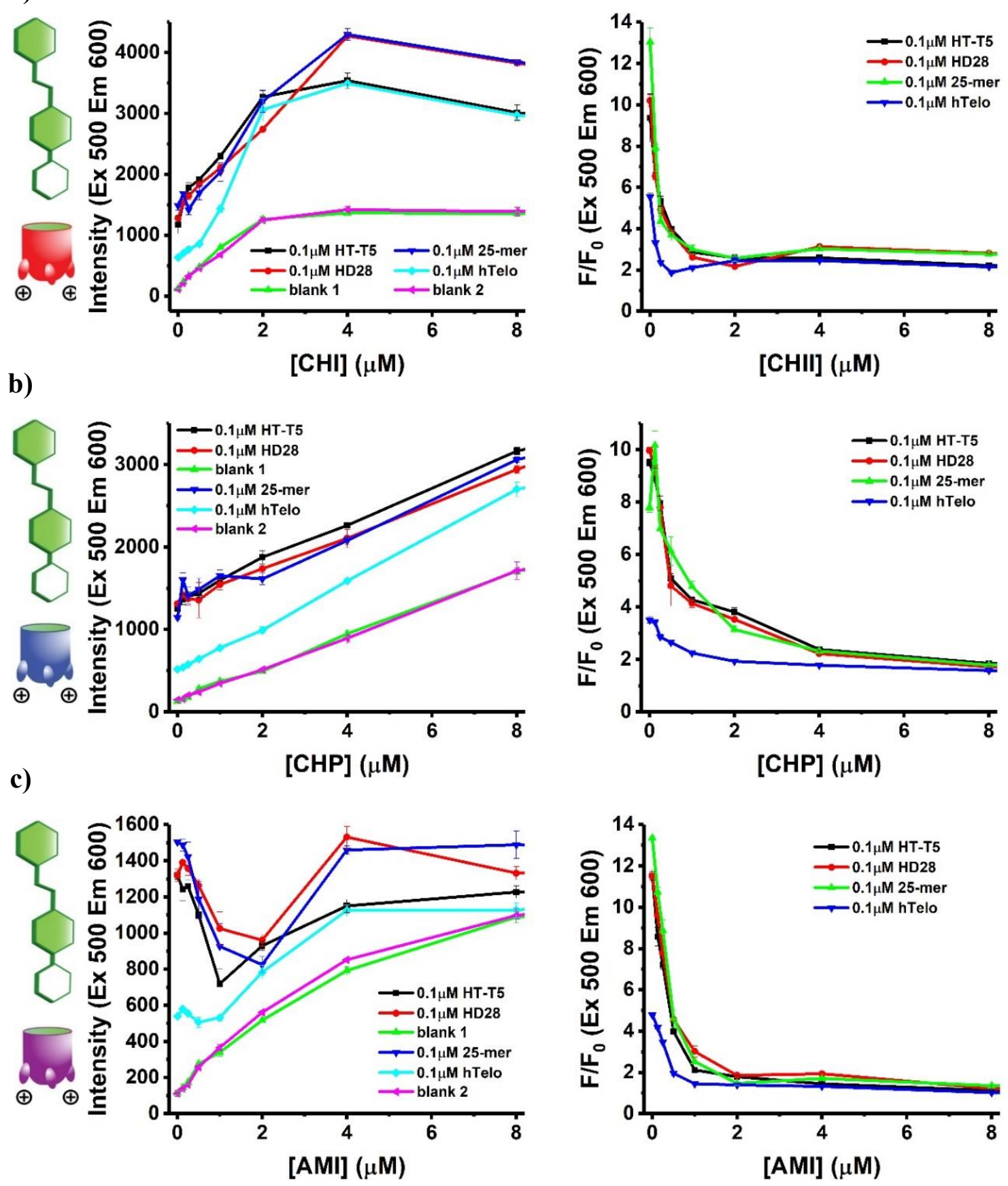

Figure $S$-10. Fluorescence response curves of PSMI-DNA complexes upon titration of hosts: a) CHI, b) CHP, and c) AMI. Left: the raw fluorescence counts (PSMI + Host); Right: plots normalized to the response of cavitand-PSMI in the absence of DNA $\left(\mathrm{F}_{0}\right)$. [PSMI $]=0.15625 \mu \mathrm{M}$, [DNA] $=0.1 \mu \mathrm{M}$, [Host $]$ $=0-16 \mu \mathrm{M}, 20 \mathrm{mM} \mathrm{CH}_{3} \mathrm{COOK}, 5 \mathrm{mM} \mathrm{MgCl}_{2}$, pH 5.5 buffer. 
a)

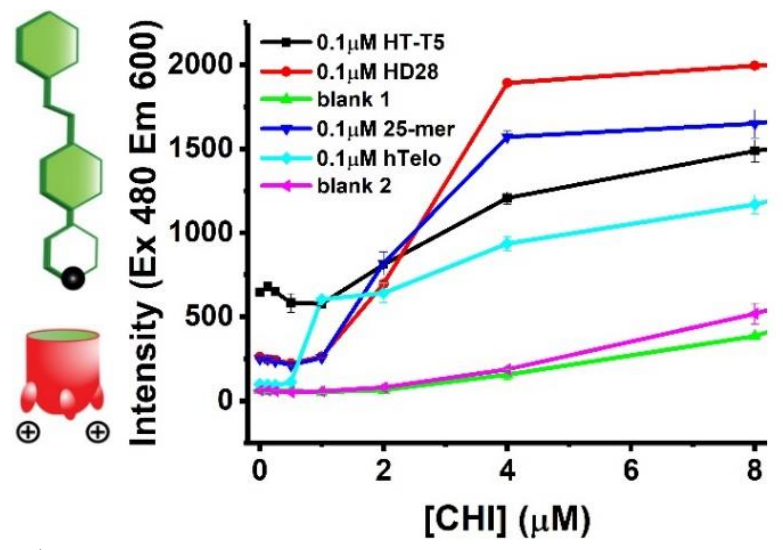

b)
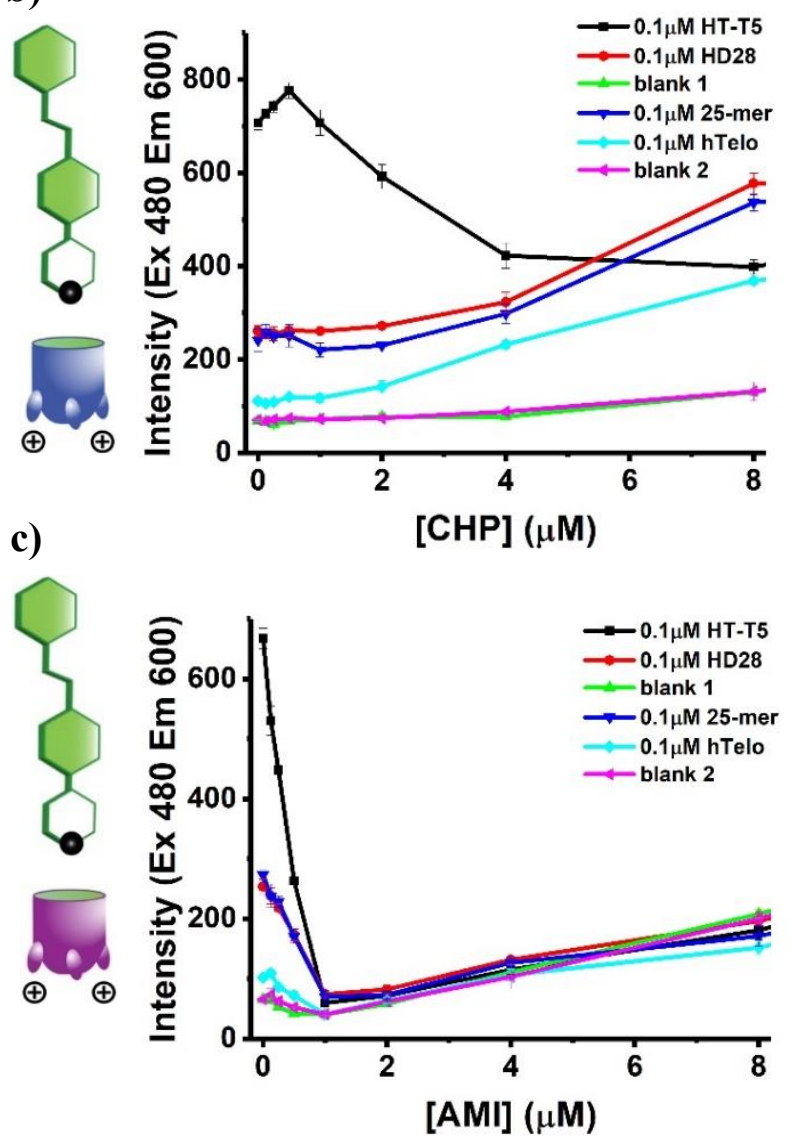
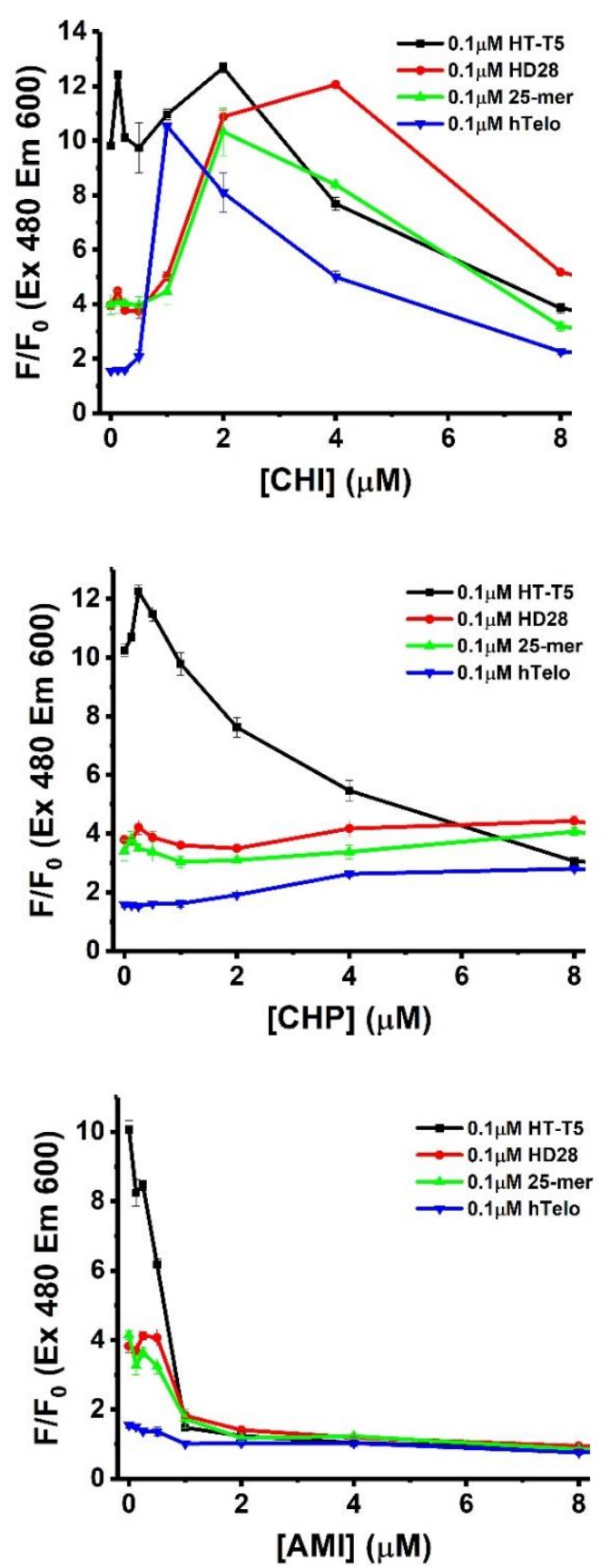

Figure $S$-11. Fluorescence response curves of MSMI•DNA complexes upon titration of hosts: a) CHI, b) CHP, and c) AMI. Left: the raw fluorescence counts (MSMI + Host); Right: plots normalized to the response of cavitand-MSMI in the absence of DNA $\left(\mathrm{F}_{0}\right)$. [MSMI $]=0.15625 \mu \mathrm{M},[\mathrm{DNA}]=0.1 \mu \mathrm{M}$, [Host] $=0-16 \mu \mathrm{M}, 20 \mathrm{mM} \mathrm{CH}_{3} \mathrm{COOK}, 5 \mathrm{mM} \mathrm{MgCl}_{2}$, pH 5.5 buffer. 

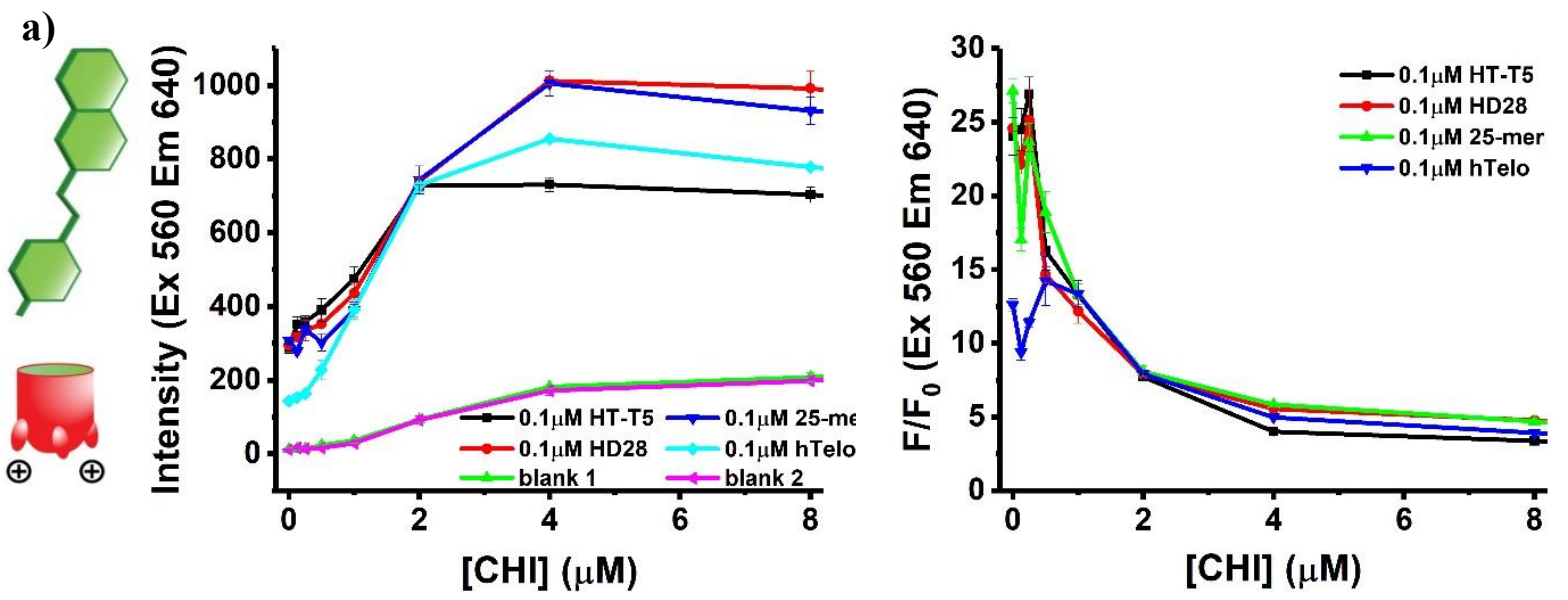

b)
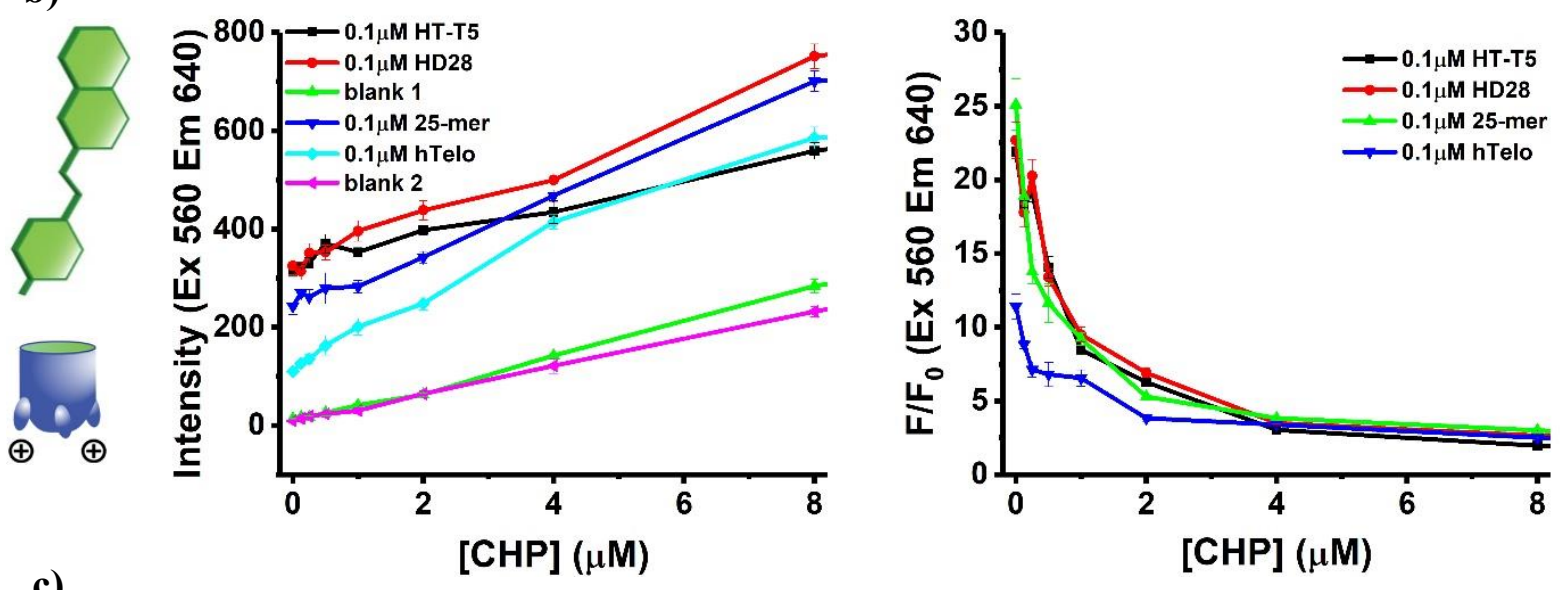

c)
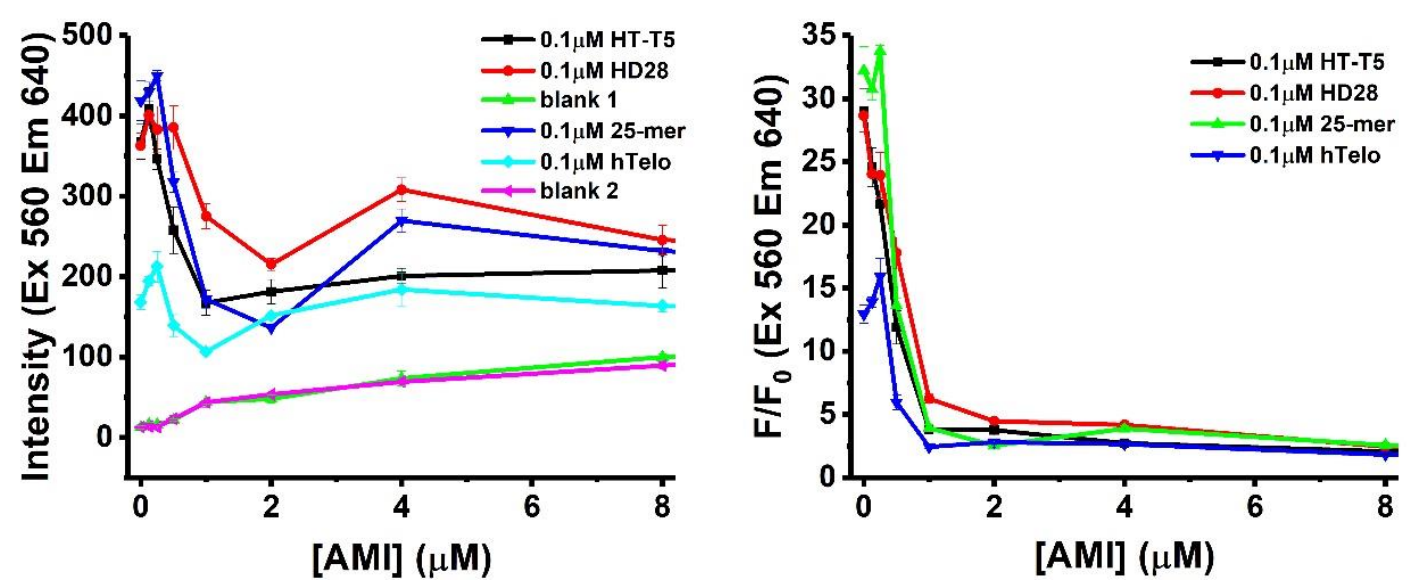

Figure $S$-12. Fluorescence response curves of DQMI•DNA complexes upon titration of hosts: a) CHI, b) CHP, and c) AMI. Left: the raw fluorescence counts (DQMI + Host); Right: plots normalized to the response of cavitand-DQMI in the absence of DNA $\left(\mathrm{F}_{0}\right)$. [DQMI] $=0.15625 \mu \mathrm{M}$, [DNA] $=0.1 \mu \mathrm{M}$, [Host] $=0-16 \mu \mathrm{M}, 20 \mathrm{mM} \mathrm{CH}_{3} \mathrm{COOK}, 5 \mathrm{mM} \mathrm{MgCl}_{2}$, pH 5.5 buffer. 


\section{Array Analysis for Differentiation of 7 DNAs}

\subsection{Bar Plots for Array Signals from 7 DNAs}
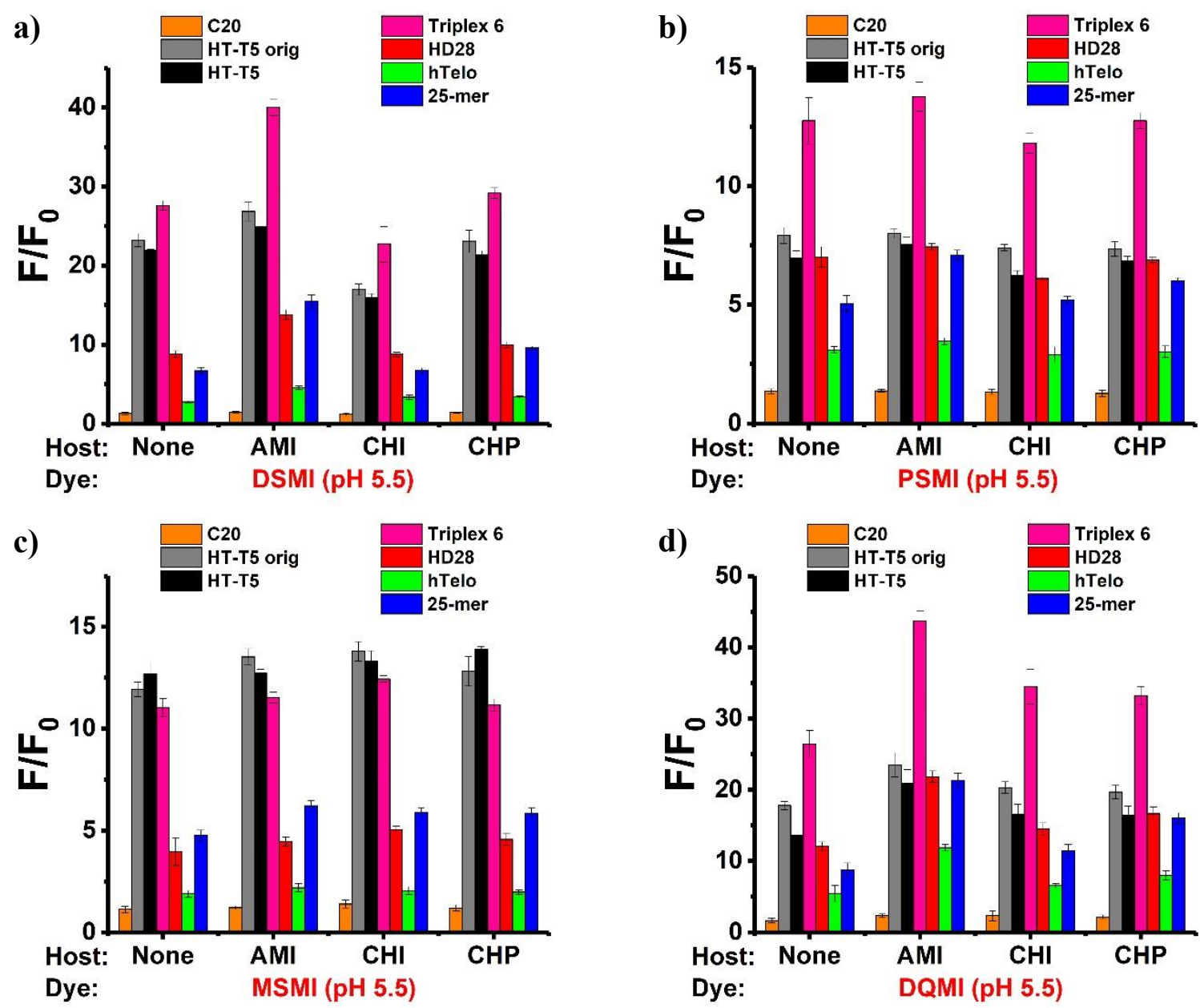

Figure $S$-13. Full fluorescence response plots of 7 DNA sequences, obtained with the full 16-element array: 4 dyes a) DSMI, b) PSMI, c) MSMI, and d) DQMI with CHI/CHP/AMI/No cavitand. [Dye] = 0.15625 $\mu \mathrm{M},[$ Host $]=0.125 \mu \mathrm{M}$, [DNA] $=0.1 \mu \mathrm{M}, 20 \mathrm{mM} \mathrm{CH}_{3} \mathrm{COOK}, 5 \mathrm{mM} \mathrm{MgCl}_{2}, \mathrm{pH} 5.5$ buffer. DSMI Ex/Em $=520 / 600 \mathrm{~nm}$, PSMI Ex/Em=500/600nm, MSMI Ex/Em=480/600nm, DQMI Ex/Em=560/640nm. 


\subsection{PCA Plots with Different Host:Guest Array Elements Combinations}
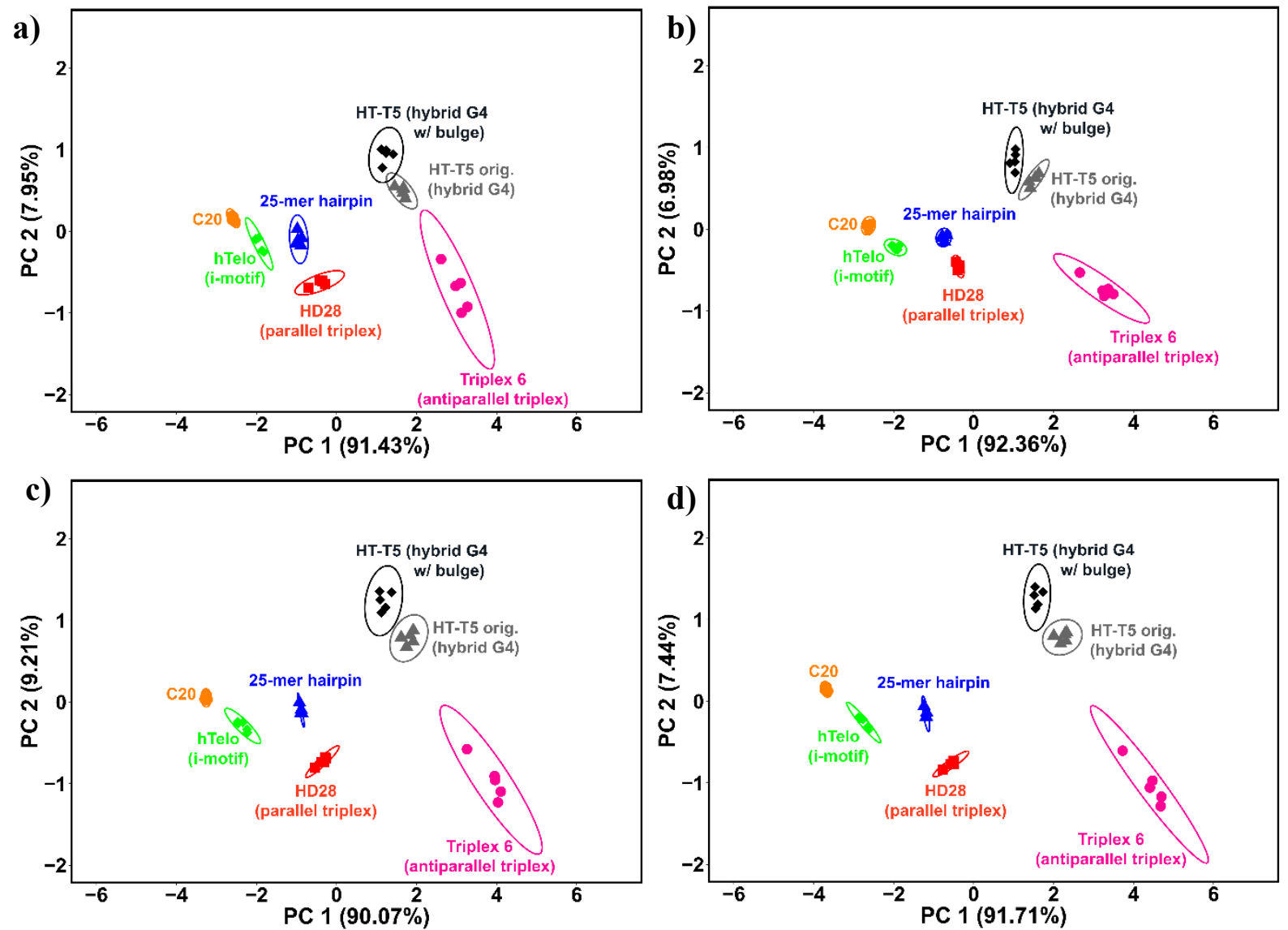

Figure $S$-14. PCA scores plot for selective sensing of 7 DNA sequences using a) four dyes only, b) four dye with CHI components, c) 6 elements: DQMI/PSMI/MSMI dyes only + DQMI/PSMI/MSMI with CHI components, d) 8 elements: four dyes only+four dyes with $\mathbf{C H I}$ components. [Dye] $=0.15625 \mu \mathrm{M}$, $[$ Host $]=0.125 \mu \mathrm{M},[\mathrm{DNA}]=0.1 \mu \mathrm{M}, 20 \mathrm{mM} \mathrm{CH}_{3} \mathrm{COOK}, 5 \mathrm{mM} \mathrm{MgCl}_{2}, \mathrm{pH} 5.5$ buffer. Ellipses indicate $95 \%$ confidence. 


\section{Array Analysis for Sensing 18 DNAs}

\subsection{Bar Plots for Array Signals from 18 DNAs}
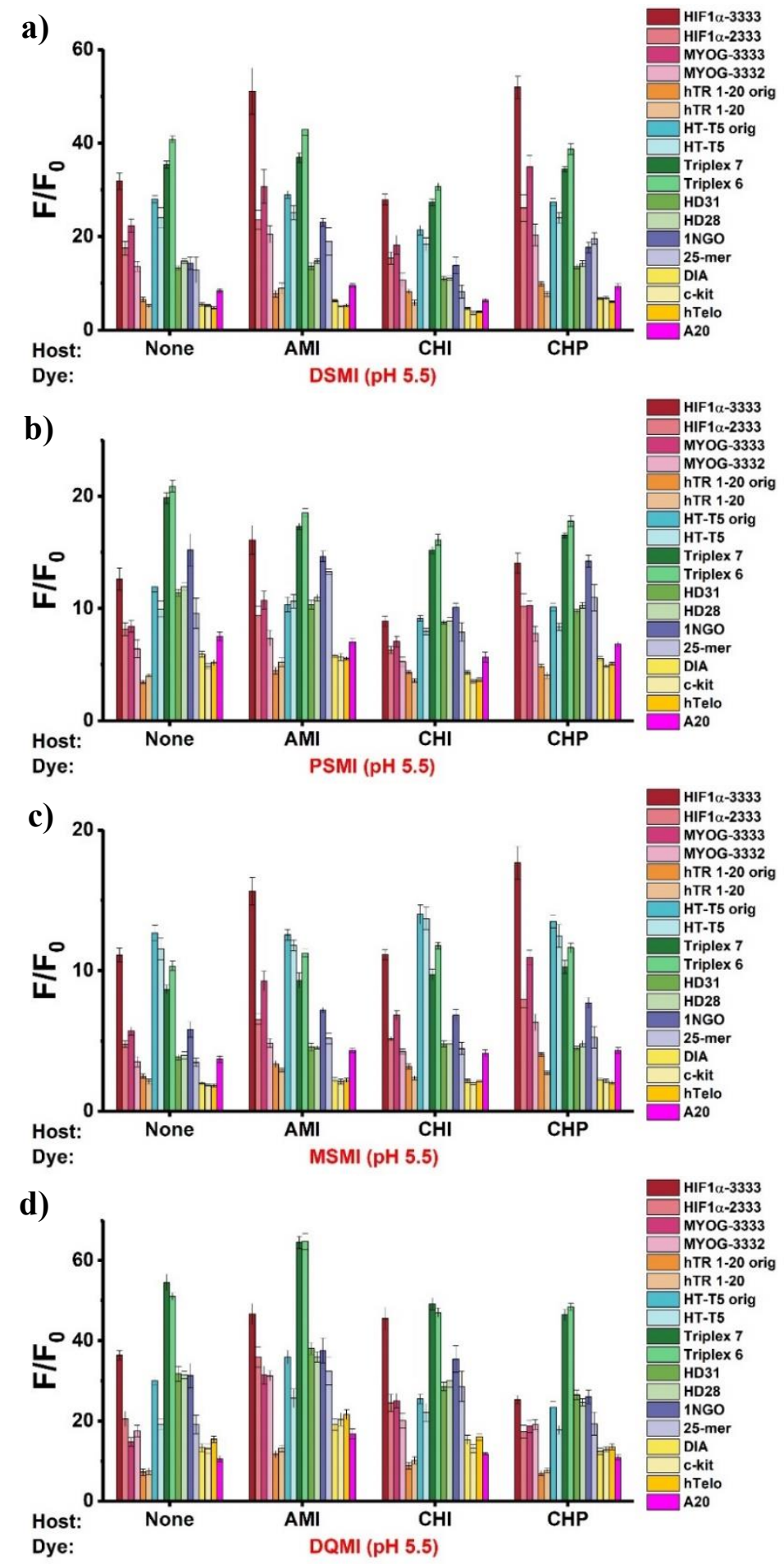

Figure $S$-15. Full fluorescence response plots of 18 DNA sequences, obtained with the full 16element array: 4 dyes a) DSMI, b) PSMI, c) MSMI, and d) DQMI with CHI/CHP/AMI/No cavitand. Sensor conditions identical to those described in Figure $S-13$. 


\subsection{SVM plot of 18 DNA training set with 16-element Host:Guest Array}
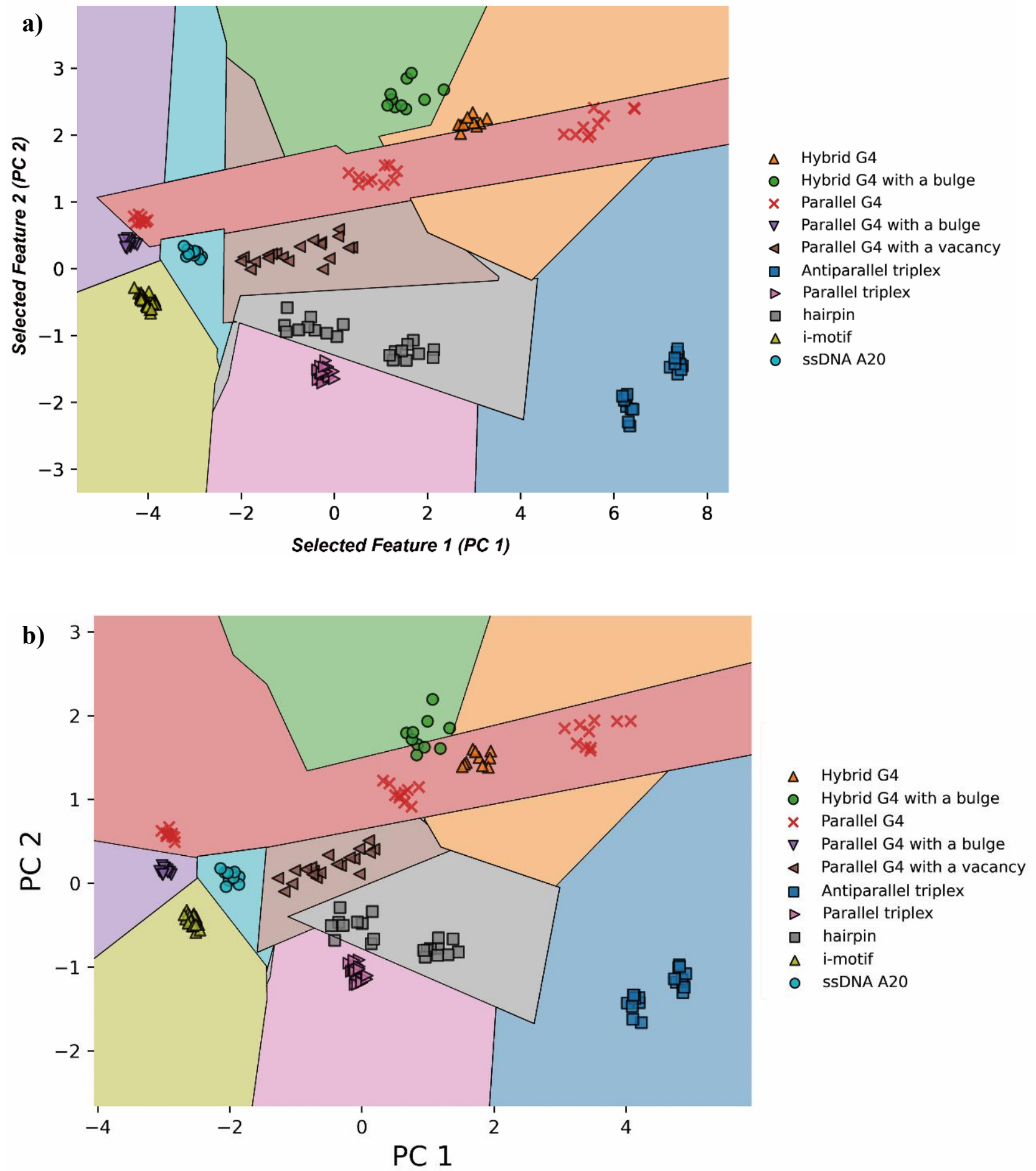

Figure $S$-16. SVM decision boundary plot of 2D PCA (using PC1 and PC 2) for classifying ten DNA classes of the training set using a) full 16-element array; or b) selected 7-element array. Sensor conditions identical to those described in Figure $S$-13. 


\subsection{Performance metrics of DNA Structures Classification}

Table $S$-2. Performance metrics of 3 repeated 8 -fold cross validation.

\begin{tabular}{|c|c|}
\hline $\begin{array}{c}\text { Evaluation } \\
\text { Metrics }\end{array}$ & $\begin{array}{c}\text { Score (standard deviation from 3 repeated running } \\
\text { of the 8-fold cross validation) }\end{array}$ \\
\hline Accuracy & $0.9812(0.0289)$ \\
\hline Sensitivity & $0.9688(0.0475)$ \\
\hline Specificity & $0.9978(0.0034)$ \\
\hline Precision & $0.9640(0.0588)$ \\
\hline F1 Score & $0.9642(0.0554)$ \\
\hline AUC & $0.9998(0.0008)$ \\
\hline
\end{tabular}

Table $S$-3. Performance metrics of each DNA class.

\begin{tabular}{|c|c|c|c|c|c|}
\hline Class & Sensitivity & Specificity & Precision & Accuracy & AUC \\
\hline Antiparallel triplex & 1.0000 & 1.0000 & 1.0000 & 1.0000 & 1.0000 \\
\hline Hybrid G4 & 0.7000 & 0.9922 & 0.8380 & 0.9759 & 0.9986 \\
\hline Hybrid G4 with a bulge & 0.9000 & 1.0000 & 1.0000 & 0.9944 & 1.0000 \\
\hline Parallel G4 & 0.9889 & 0.9800 & 0.9085 & 0.9815 & 0.9991 \\
\hline Parallel G4 with a bulge & 1.0000 & 1.0000 & 1.0000 & 1.0000 & 1.0000 \\
\hline $\begin{array}{c}\text { Parallel G4 with a } \\
\text { vacancy }\end{array}$ & 1.0000 & 1.0000 & 1.0000 & 1.0000 & 1.0000 \\
\hline Parallel triplex & 1.0000 & 1.0000 & 1.0000 & 1.0000 & 1.0000 \\
\hline hairpin & 1.0000 & 1.0000 & 1.0000 & 1.0000 & 1.0000 \\
\hline i-motif & 1.0000 & 1.0000 & 1.0000 & 1.0000 & 1.0000 \\
\hline ssDNA & 1.0000 & 1.0000 & 1.0000 & 1.0000 & 1.0000 \\
\hline
\end{tabular}




\section{Folding prediction of unknown DNA structures}

6.1 Fluorescence response plots of unknown DNA structures

a) APE 1-4 track

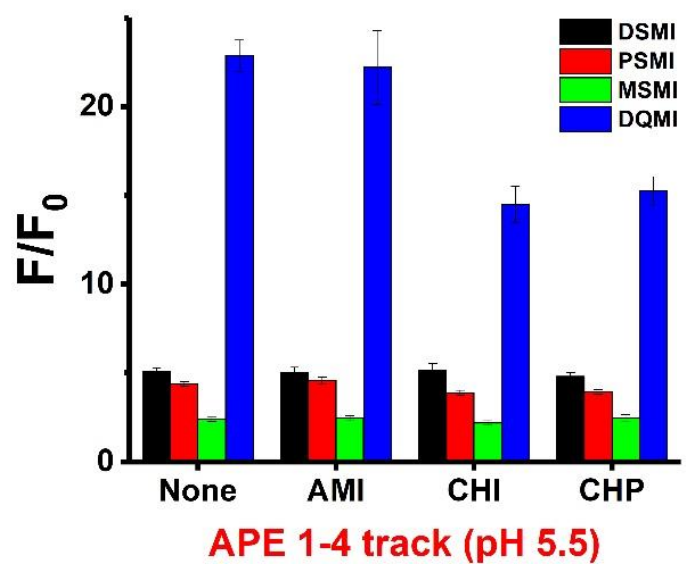

b) $\mathbf{G} 20$

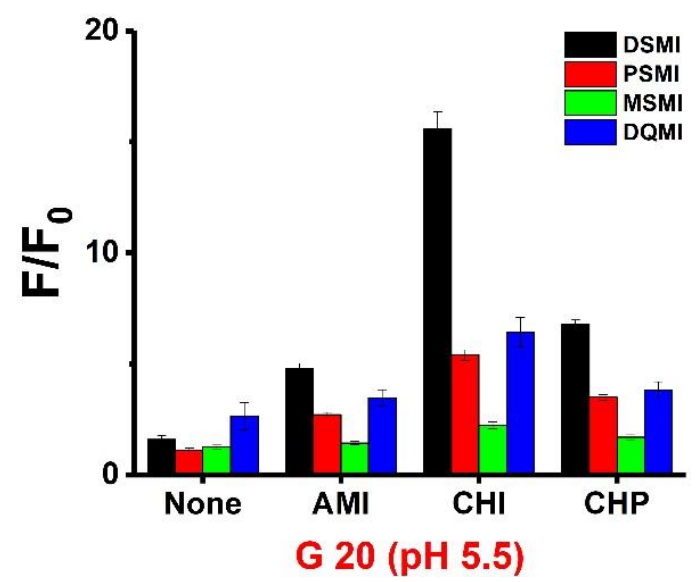

c) c-myc 2345

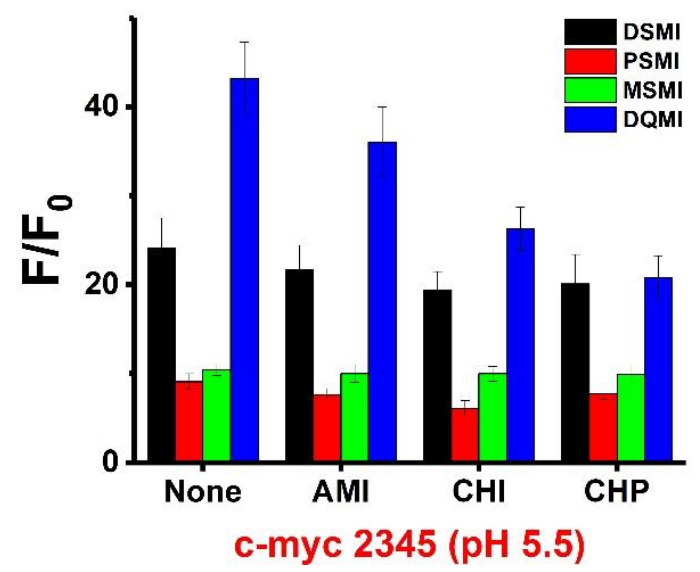




\section{d) EAD4}

e) Telo24
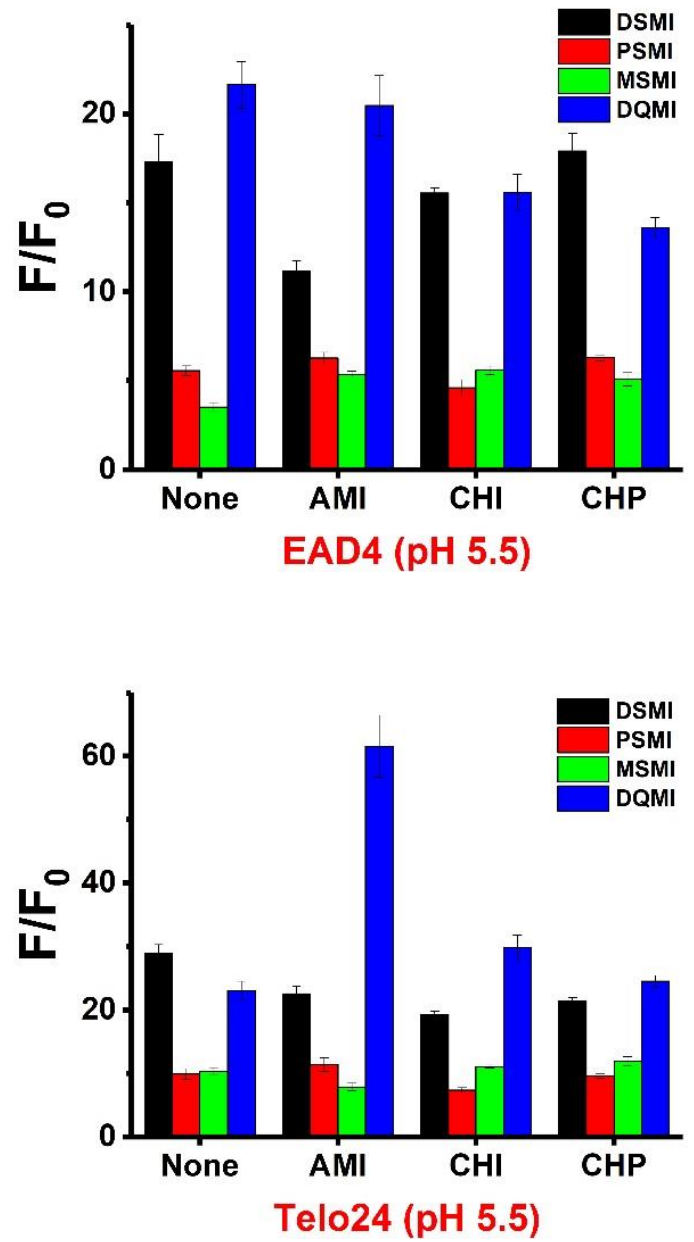

Figure $S$-17. Full fluorescence response plots of unknown DNA a) APE 1-4 track, b) G 20, c) c-myc 2345, d) EAD4, and e) Telo24 obtained with the full 16-element array. Sensor conditions identical to those described in Figure $S$-13. 


\subsection{SVM decision boundary plot for prediction results}

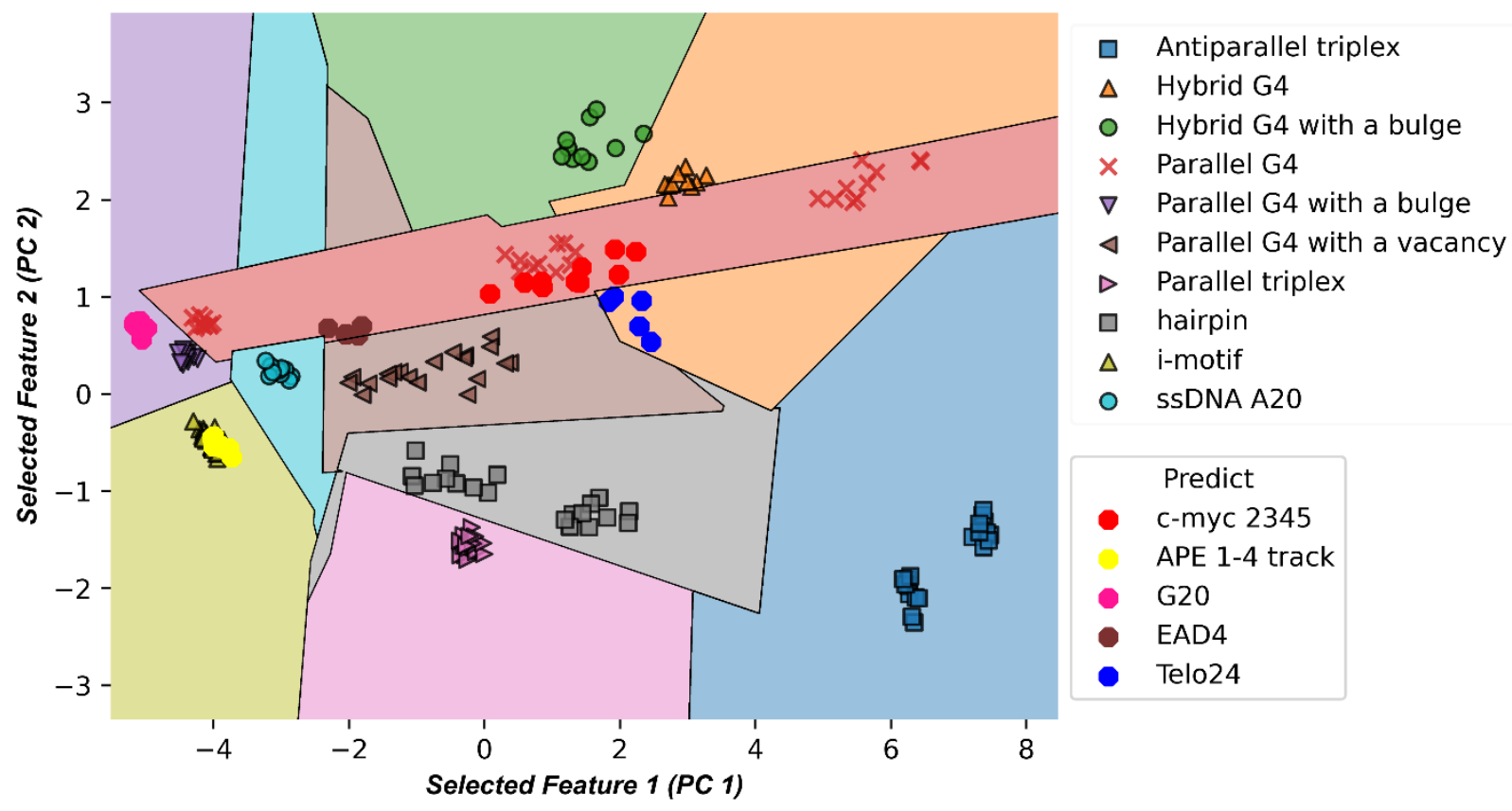

Figure $S$-18. Prediction of unknown DNAs by using the model of 18 DNA training set with 16-element Host:Guest Array. Sensor conditions identical to those described in Figure $S-13$, and the image is identical to that shown in Figure 5, with the DNAs labeled by folding type, not individual strand. 


\section{UV-Vis Absorbance Spectra}

\subsection{UV-Vis Spectra of Dye-DNA}
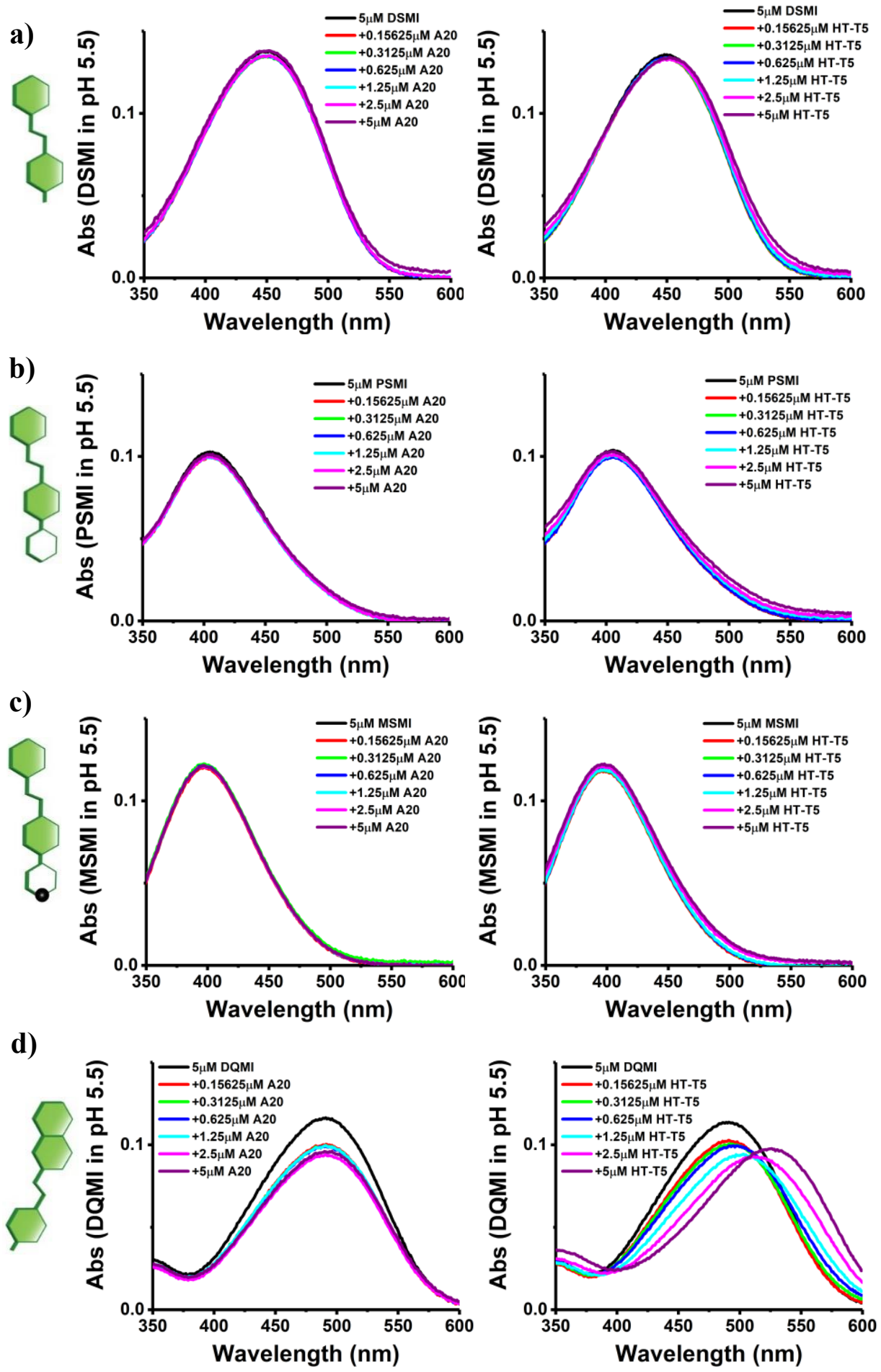

Figure $\boldsymbol{S}$-19. UV spectra of Dyes 4 dyes a) DSMI, b) PSMI, c) MSMI, and d) DQMI with increasing concentration of DNA. Left: Dye+A20; Right: Dye+HT-T5. [Dye] $=5 \mu \mathrm{M}$, [DNA] $=0-5 \mu \mathrm{M}, 20 \mathrm{mM}$ $\mathrm{CH}_{3} \mathrm{COOK}, 5 \mathrm{mM} \mathrm{MgCl}$, $\mathrm{pH} 5.5$ buffer. 


\subsection{UV-Vis Spectra of DNA Addition to Dye•Host Complexes}

a)

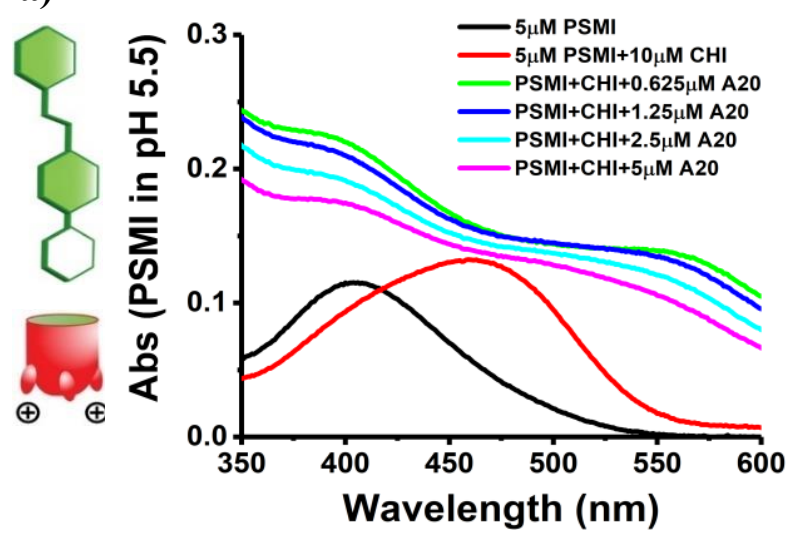

b)

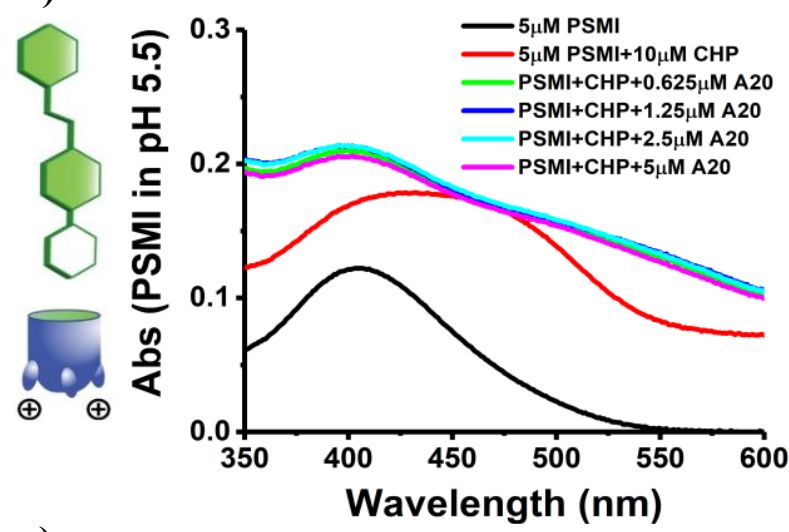

c)

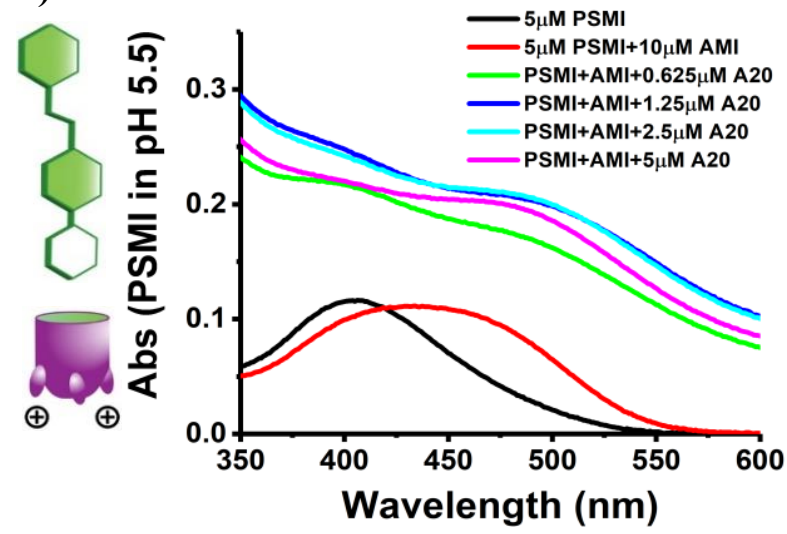

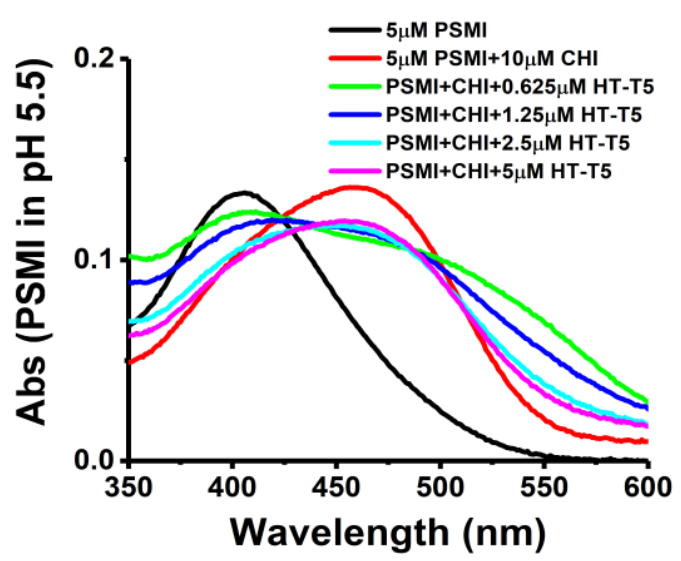
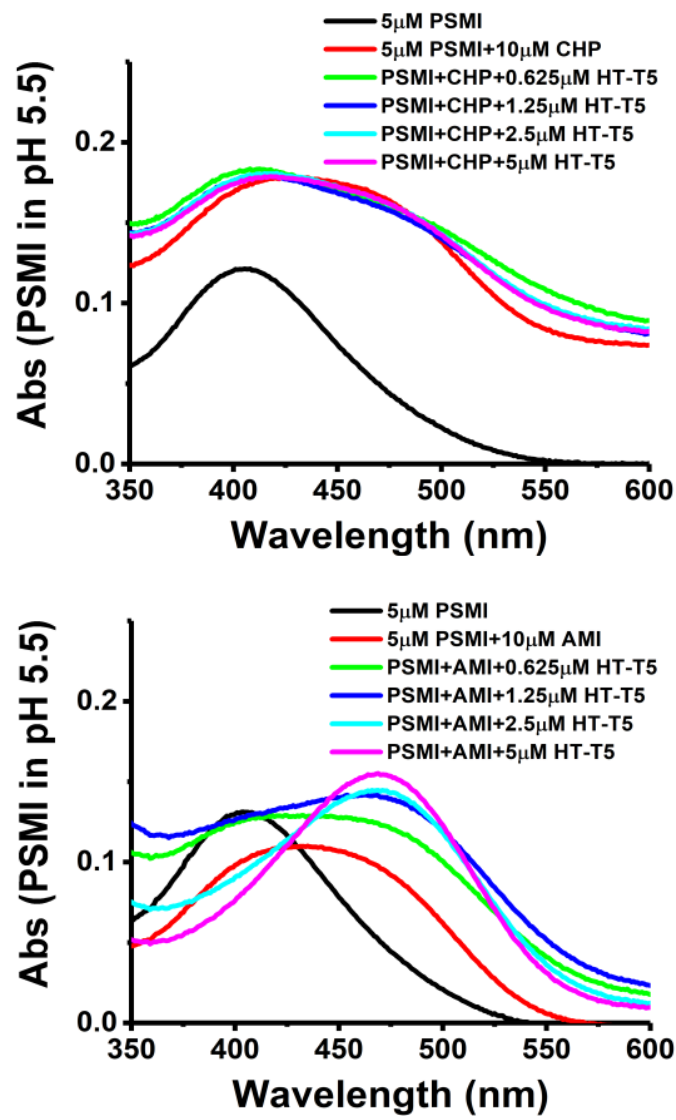

Figure $S$-20. UV spectra of PSMI•Host complexes a) CHI, b) CHP, and c) AMI upon titration of DNA. Left: PSMI+Host+A20; Right: PSMI+Host+HT-T5. [PSMI] $=5 \mu \mathrm{M},[$ Host $]=10 \mu \mathrm{M},[\mathrm{DNA}]=0-5 \mu \mathrm{M}$, $20 \mathrm{mM} \mathrm{CH}_{3} \mathrm{COOK}, 5 \mathrm{mM} \mathrm{MgCl} 2$, $\mathrm{pH} 5.5$ buffer. 

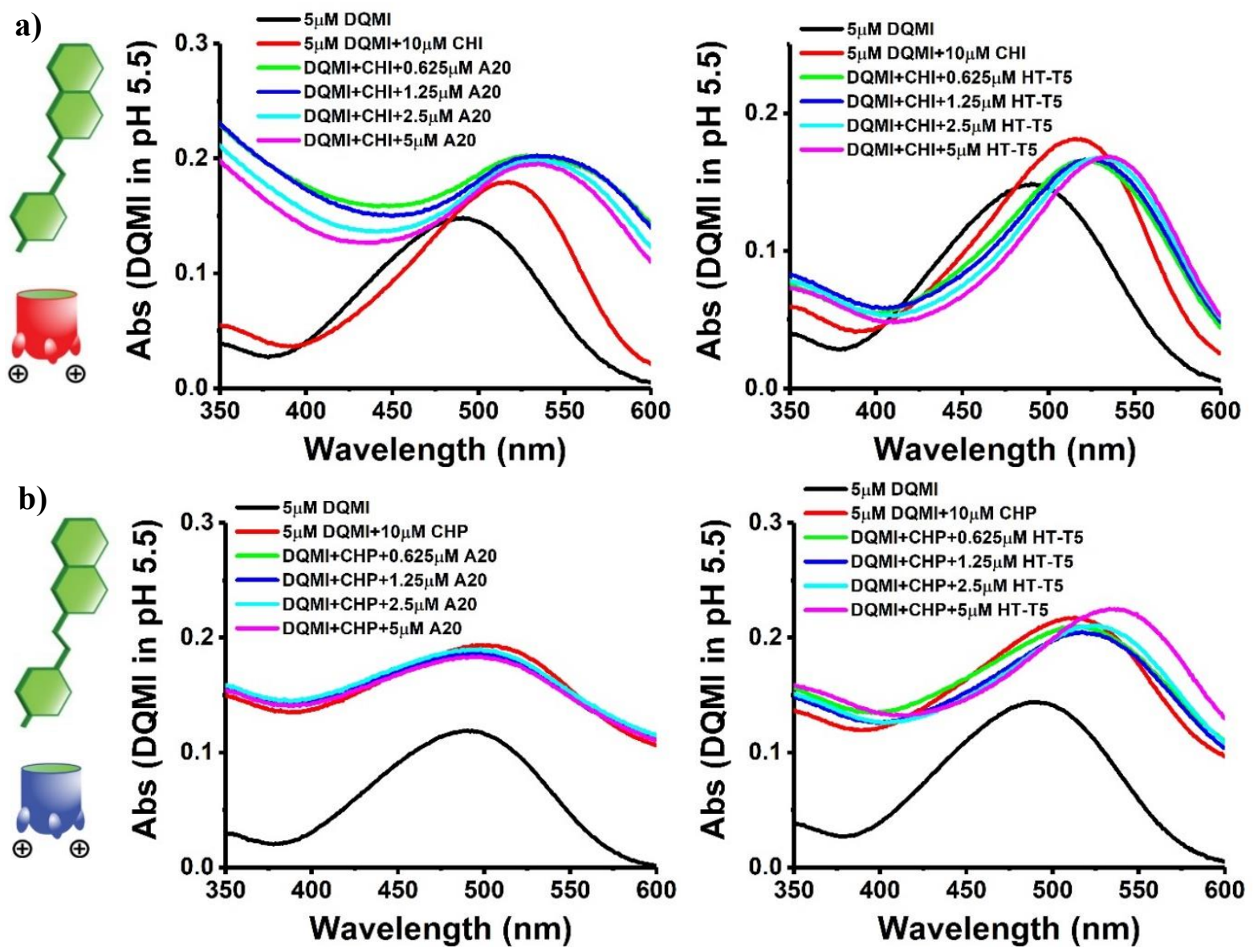

c)
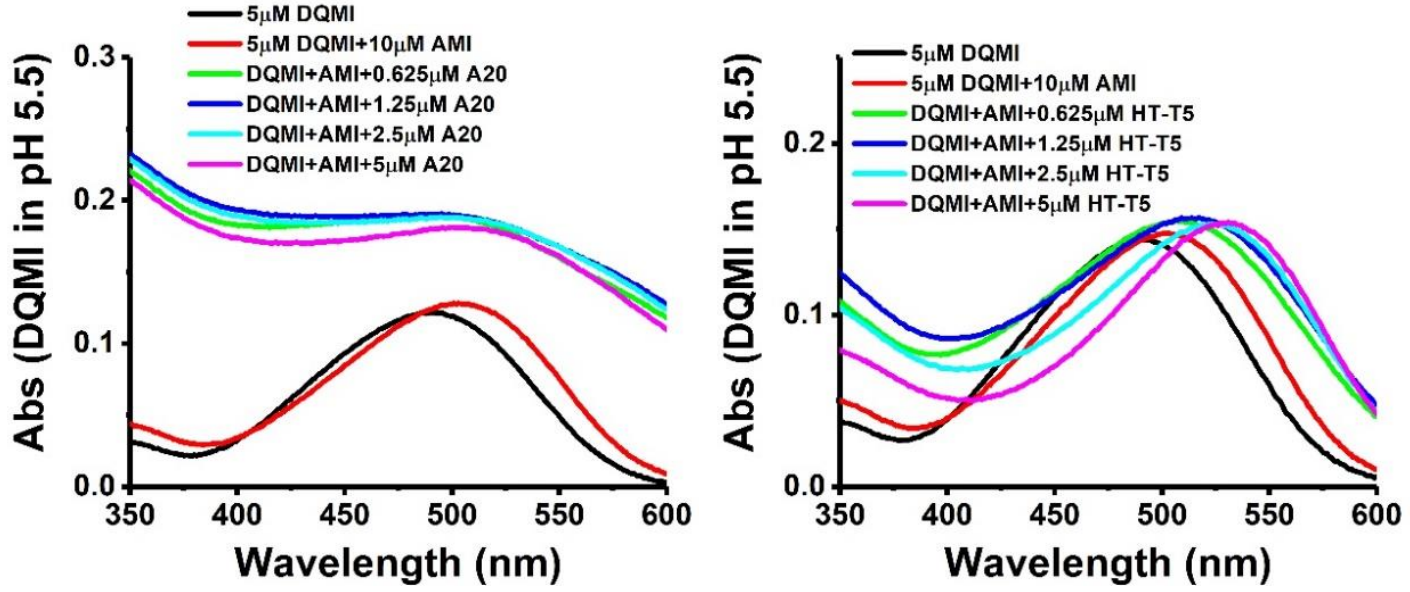

Figure $S$-21. UV spectra of DQMI•Host complexes a) CHI, b) CHP, and c) AMI upon titration of DNA. Left: DQMI+Host+A20; Right: DQMI+Host+HT-T5. [DQMI] $=5 \mu \mathrm{M}$, [Host] $=10 \mu \mathrm{M}$, [DNA] $=0-5$ $\mu \mathrm{M}, 20 \mathrm{mM} \mathrm{CH}_{3} \mathrm{COOK}, 5 \mathrm{mM} \mathrm{MgCl}$, $\mathrm{pH} 5.5$ buffer. 


\section{References}

1. He, Y.-D.; Zheng, K.-W.; Wen, C.-J.; Li, X.-M.; Gong, J.-Y.; Hao, Y.-H.; Zhao, Y.; Tan, Z. Selective Targeting of Guanine-Vacancy-Bearing G-Quadruplexes by G-Quartet Complementation and Stabilization with a Guanine-Peptide Conjugate. J. Am. Chem. Soc. 2020, 142, 11394-11403.

2. Li, X.-M.; Zheng, K.-W.; Zhang, J.-Y.; Liu, H.-H.; He, Y.-D.; Yuan, B.-F.; Hao, Y.-H.; Tan, Z. Guanine-vacancy-bearing G-quadruplexes Responsive to Guanine Derivatives. Proc. Natl. Acad. Sci. U.S.A. 2015, 112, 14581-14586.

3. Meier, M.; Moya-Torres, A.; Krahn, N. J.; McDougall, M. D.; Orriss, G. L.; McRae, E. K. S.; Booy, E. P.; McEleney, K.; Patel, T. R.; McKenna, S. A.; Stetefeld, J. Structure and Hydrodynamics of a DNA G-quadruplex with a Cytosine Bulge. Nucleic Acids Res. 2018, 46, 5319-5331.

4. Mukundan, V. T.; Phan, A. T. Bulges in G-Quadruplexes: Broadening the Definition of GQuadruplex-Forming Sequences. J. Am. Chem. Soc. 2013, 135, 5017-5028.

5. Phan, A. T.; Guéron, M.; Leroy, J.-L. The Solution Structure and Internal Motions of a Fragment of the Cytidine-rich Strand of the Human Telomere. J. Mol. Biol. 2000, 299, 123144.

6. Day, H. A.; Pavlou, P.; Waller, Z. A. E., i-Motif DNA: Structure, Stability and Targeting with Ligands. Bioorg. Med. Chem. 2014, 22, 4407-4418.

7. Choi, J.; Kim, S.; Tachikawa, T.; Fujitsuka, M.; Majima, T. pH-Induced Intramolecular Folding Dynamics of i-Motif DNA. J. Am. Chem. Soc. 2011, 133, 16146-16153.

8. Sklenár, V.; Felgon, J. Formation of a Stable Triplex from a Single DNA Strand. Nature 1990, 345, 836-838.

9. Macaya, R.; Wang, E.; Schultze, P.; Sklenáŕ, V.; Feigon, J., Proton Nuclear Magnetic Resonance Assignments and Structural Characterization of an Intramolecular DNA Triplex. J. Mol. Biol. 1992, 225, 755-773.

10. Radhakrishnan, I.; de los Santos, C.; Patel, D. J. Nuclear Magnetic Resonance Structural Studies of Intramolecular Purine - Purine - Pyrimidine DNA Triplexes in Solution: Base Triple Pairing Alignments and Strand Direction. J. Mol. Biol. 1991, 221, 1403-1418.

11. Ma, H.; Wan, C.; Wu, A.; Zewail, A. H. DNA Folding and Melting Observed in Real Time Redefine the Energy Landscape. Proc. Natl. Acad. Sci. U.S.A. 2007, 104, 712-716.

12. Shiflett, P. R.; Taylor-McCabe, K. J.; Michalczyk, R.; Silks, L. A. P.; Gupta, G. Structural Studies on the Hairpins at the $3^{6}$ Untranslated Region of an Anthrax Toxin Gene. Biochemistry 2003, 42, 6078-6089.

13. Greve, J.; Maestre, M. F.; Levin, A. Circular Dichroism of Adenine and Thymine Containing Synthetic Polynucleotides. Biopolymers 1977, 16, 1489-1504.

14. Chakraborty, S.; Sharma, S.; Maiti, P. K.; Krishnan, Y. The Poly dA Helix: a New Structural Motif for High Performance DNA-based Molecular Switches. Nucleic Acids Res. 2009, 37, 2810-2817.

15. Rogers, R. A.; Fleming, A. M.; Burrows, C. J. Unusual Isothermal Hysteresis in DNA iMotif pH Transitions: A Study of the RAD17 Promoter Sequence. Biophys. J. 2018, 114, 1804-1815.

16. Rogers, R. A.; Fleming, A. M.; Burrows, C. J. Rapid Screen of Potential i-Motif Forming Sequences in DNA Repair Gene Promoters. ACS Omega 2018, 3, 9630-9635.

17. Jin, M.; Liu, X.; Zhang, X.; Wang, L.; Bing, T.; Zhang, N.; Zhang, Y.; Shangguan, D. Thiazole Orange-Modified Carbon Dots for Ratiometric Fluorescence Detection of G- 
Quadruplex and Double-Stranded DNA. ACS Appl. Mater. Interfaces 2018, 10, 2516625173.

18. Yang, Q.; Xiang, J.; Yang, S.; Li, Q.; Zhou, Q.; Guan, A.; Zhang, X.; Zhang, H.; Tang, Y.; $\mathrm{Xu}, \mathrm{G}$. Verification of Specific G-quadruplex Structure by Using a Novel Cyanine Dye Supramolecular Assembly: II. The Binding Characterization with Specific Intramolecular G-quadruplex and the Recognizing Mechanism. Nucleic Acids Res. 2010, 38, 1022-1033.

19. Lin, D.; Fei, X.; Gu, Y.; Wang, C.; Tang, Y.; Li, R.; Zhou, J. A Benzindole Substituted Carbazole Cyanine Dye: a Novel Targeting Fluorescent Probe for Parallel c-myc Gquadruplexes. Analyst 2015, 140, 5772-5780.

20. Sengar, A.; Heddi, B.; Phan, A. T. Formation of G-Quadruplexes in Poly-G Sequences: Structure of a Propeller-Type Parallel-Stranded G-Quadruplex Formed by a G15 Stretch. Biochemistry 2014, 53, 7718-7723.

21. Panyutin, I. G.; Kovalsky, O. I.; Budowsky, E. I.; Dickerson, R. E.; Rikhirev, M. E.; Lipanov, A. A. G-DNA: a Twice-folded DNA Structure Adopted by Single-stranded Oligo(dG) and Its Implications for Telomeres. Proc. Natl. Acad. Sci. U.S.A. 1990, 87, 867870.

22. Joly, L.; Rosu, F.; Gabelica, V. d(TG $\left.\mathrm{TG}_{\mathrm{n}} \mathrm{T}\right)$ DNA Sequences Do Not Necessarily Form Tetramolecular G-quadruplexes. Chem. Commun. 2012, 48, 8386-8388.

23. Cheng, X.; Liu, X.; Bing, T.; Cao, Z.; Shangguan, D. General Peroxidase Activity of GQuadruplex-Hemin Complexes and Its Application in Ligand Screening. Biochemistry 2010, 48, 7817-7823.

24. Ma, Y.; Tsushima, Y.; Sakuma, M.; Sasaki, S.; Iida, K.; Okabe, S.; Seimiya, H.; Hirokawa, T.; Nagasawa, K. Development of G-quadruplex ligands for selective induction of a parallel-type topology. Org. Biomol. Chem. 2018, 16, 7375-7382. 